\title{
Identification of a new stony coral host for the anemone shrimp Periclimenes rathbunae Schmitt, 1924 with notes on the host-use pattern
}

\author{
Bregje W. Brinkmann ${ }^{1,2}$, Charles H.J.M. Fransen ${ }^{1}$ \\ ${ }^{1}$ Naturalis Biodiversity Center, P.O. Box 9517, 2300 RA Leiden, The Netherlands \\ ${ }^{2}$ Email: bregjebrinkmann@gmail.com
}

Key words: $16 \mathrm{~S}, \mathrm{COI}$, cryptic species, Curaçao, $\mathrm{H3}$, new host, Palaemonidae, phylogeny, Scleractinia

\begin{abstract}
Periclimenes rathbunae Schmitt, 1924 is a western Atlantic symbiotic shrimp species mainly associating with anemones. Adult shrimps of $P$. rathbunae are characterised by an orangewhite spotted colour pattern. During fieldwork along the coast of Curaçao (2013), morphologically similar, though generally smaller sized shrimps were collected from the stony coral Dendrogyra cylindrus Ehrenberg, 1834. These specimens were overall more translucent. This study elucidates the taxonomic status of the coral-associated specimens in relation to anemone-associated specimens of $P$. rathbunae and related anemone-associated species using one nuclear (histone $\mathrm{H} 3, \mathrm{H3}$ ), a mitochondrial protein-coding (cytochrome oxidase subunit I, COI) and a mitochondrial ribosomal RNA (16S) gene. Molecular phylogenetic reconstructions clustered the coral-associated specimens with anemone-associated $P$. rathbunae within a distinct clade, revealing that the aberrant coral-associated shrimp specimens belong to $P$. rathbunae. It can be concluded that 1$)$ the stony coral $D$. cylindrus is a host of $P$. rathbunae, constituting the first record of an association between a scleractinian coral and a palaemonid shrimp species in the Atlantic Ocean; 2) the colour pattern of $P$. rathbunae is a phenotypically plastic characteristic that varies with size and is depending on the host species; and 3) mean body size of $P$. rathbunae is smaller on $D$. cylindrus than on the anemone Stichodactyla helianthus. This raises interesting questions about patterns of host use for this species and warrants further in-depth field ecological study for this species.
\end{abstract}

\section{Contents}

Introduction 437

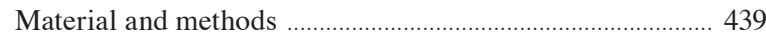

Sampling ................................................................................ 439

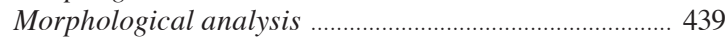

DNA extraction ................................................................. 439

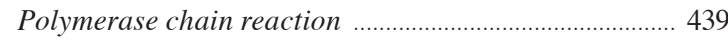

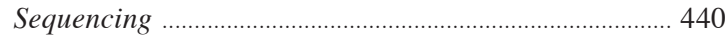

Molecular phylogenetic analyses ..................................... 441

Results

Morphological comparison ……..................................... 441

Phylogenetic position of the coral-associated specimens 442

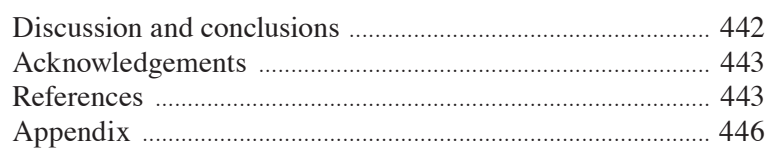

\section{Introduction}

Counting over 150 species, Periclimenes Costa, 1844 is one of the most speciose genera of the caridean shrimp family Palaemonidae Rafinesque, 1815 (De Grave and Fransen, 2011; Mitsuhashi et al., 2012; De Grave, 2014). Its species are dispersed in marine waters all over the world, few are free-living, the majority associates with mostly sessile or slow-moving benthic invertebrates (Bruce, 2007). The ubiquity of cryptic species - generally defined as at least superficially morphologically indistinguishable species (Bickford $e t$ al., 2006) - among marine habitats (Knowlton, 1993) casts doubt on Periclimenes' current species count.

The present study focuses on the species boundaries of the symbiotic shrimp Periclimenes rathbunae Schmitt, 1924. Occurring in shallow, tropical waters of the western Atlantic, P. rathbunae is widely reported to associate with anemones (Spotte et al., 1991; Hayes and Trimm, 2008), including Bartholomea annulata (Le Sueur, 1817), Bunodosoma granuliferum (Le Sueur, 1817), Condylactis gigantea (Weinland, 1860), Homostichanthus duerdeni (Carlgren, 1900), Lebrunia danae (Duchassaing and Michelotti, 1860) (= Lebrunia neglecta Duchassaing and Michelotti, 1860), Stichodactyla helianthus (Ellis, 1768), and Exaiptasia pallida (Agassiz in Verrill, 1864). Furthermore, soft coral Eunicea tourneforti Milne Edwards and Haime, 1857 has been documented to host $P$. rathbunae (cf. Hayes and Trimm, 2008). Reports of P. rathbunae on other hosts are scarce. From 1982 till 2006, P. rathbunae has only been reported to associate with corallimorph Ricordea florida Duchassaing and Michelotti, 


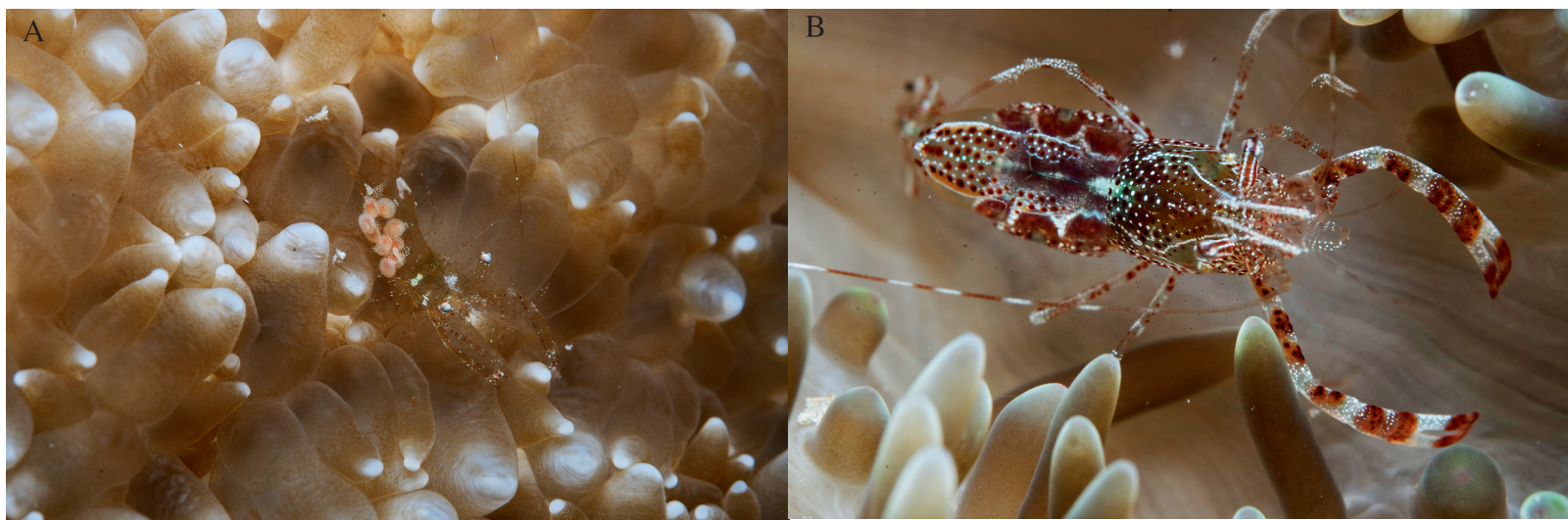

Fig. 1. Periclimenes rathbunae Schmitt, 1924. A, on the stony coral Dendrogyra cylindrus Ehrenberg, 1834, Curaçao, Cas Abou $(12.227861 \mathrm{~N}, 69.091778 \mathrm{~W})$, photograph by S.E.T. van der Meij; B, on the anemone Stichodactyla heliantus (Ellis, 1768), (BW0060), Curaçao, Car Wrecks (12.161N, 69.004083W), photograph by C.H.J.M. Fransen.

1860 three times (Ritson-Williams and Paul, 2007). Notably, symbioses with Scleractinia have never been reported for any Atlantic palaemonid shrimp species.

During fieldwork along the coast of Curaçao (2013), shrimps that are morphologically similar to P. rathbunae were collected from a scleractinian coral, Dendrogyra cylindrus Ehrenberg, 1834. The overall more translucent appearance of the newly obtained specimens clearly differed from the orange-white spotted colour pattern of larger adult $P$. rathbunae as described by Spotte et al. (1991) (Fig. 1A, B). Since differences in ecology and colour pattern often function as diagnostics to identify decapod cryptic species living in sympatry (Knowlton, 1993; Knowlton, 2000), the coral-associated specimens were expected to belong to a yet unidentified cryptic species of Periclimenes.

Here, the specimens of Periclimenes hosted by $D$. cylindrus are described morphologically and compared to anemone-associated shrimps of $P$. rathbunae. As the original description of the species is rather brief, a detailed re-description has been provided (Appendix).

Using a DNA barcoding approach, the aim of this study was to unravel the phylogenetic relationships of the coral and anemone-associated specimens. Partial sequences of the mitochondrial cytochrome oxidase subunit I (COI) gene, the mitochondrial ribosomal

Table 1. Analysed specimens with species name, sample number, collection registration number, sampling locality, host and GenBank

\begin{tabular}{|c|c|c|c|c|}
\hline \multirow[t]{2}{*}{ Species } & \multicolumn{4}{|c|}{ Locality } \\
\hline & Sample nr & Voucher reg. nr & Name & Coordinates \\
\hline Ancylomenes pedersoni (Chace, 1958) & BW0010 & RMNH.CRUS.D.56996 & Hilton Reef & $12.121789 \mathrm{~N}, 68.969508 \mathrm{~W}$ \\
\hline Ancylomenes pedersoni (Chace, 1958) & BW0020 & RMNH.CRUS.D.56997 & Playa Forti & $12.366139 \mathrm{~N}, 69.15375 \mathrm{~W}$ \\
\hline Periclimenes yucatanicus (Ives, 1890) & BW0030 & RMNH.CRUS.D.56998 & Playa Boka Sami & $12.147611 \mathrm{~N}, 68.99875 \mathrm{~W}$ \\
\hline Periclimenes yucatanicus (Ives, 1890) & BW0040 & RMNH.CRUS.D.56999 & Playa Forti & $12.366139 \mathrm{~N}, 69.15375 \mathrm{~W}$ \\
\hline Periclimenes rathbunae Schmitt, 1924 & BW0050 & RMNH.CRUS.D.57034 & Hilton Reef & $12.121789 \mathrm{~N}, 68.969508 \mathrm{~W}$ \\
\hline Periclimenes rathbunae Schmitt, 1924 & BW0060 & RMNH.CRUS.D.57036 & Car Wrecks & $12.161 \mathrm{~N}, 69.004083 \mathrm{~W}$ \\
\hline Periclimenes rathbunae Schmitt, 1924 & BW0070 & RMNH.CRUS.D.57035 & Playa Forti & $12.366139 \mathrm{~N}, 69.15375 \mathrm{~W}$ \\
\hline Periclimenes rathbunae Schmitt, 1924 & BW0170 & RMNH.CRUS.D.57032 & Cas Abou & $12.227861 \mathrm{~N}, 69.091778 \mathrm{~W}$ \\
\hline Periclimenes rathbunae Schmitt, 1924 & BW0171 & RMNH.CRUS.D.57032 & Cas Abou & $12.227861 \mathrm{~N}, 69.091778 \mathrm{~W}$ \\
\hline Periclimenes rathbunae Schmitt, 1924 & BW0180 & RMNH.CRUS.D.57031 & Marie Pampoen & $12.090761 \mathrm{~N}, 68.904956 \mathrm{~W}$ \\
\hline Periclimenes rathbunae Schmitt, 1924 & BW0181 & RMNH.CRUS.D.57031 & Marie Pampoen & $12.090761 \mathrm{~N}, 68.904956 \mathrm{~W}$ \\
\hline Periclimenes rathbunae Schmitt, 1924 & BW0190 & RMNH.CRUS.D.57033 & Grote Knip & $12.351139 \mathrm{~N}, 69.151917 \mathrm{~W}$ \\
\hline Gnathophylloides mineri Schmitt, 1933 & BW1050 & RMNH.CRUS.D.57000 & W Piscadera Baai & $12.12275 \mathrm{~N}, 68.970428 \mathrm{~W}$ \\
\hline Ascidonia quasipusilla (Chace, 1972) & BW1200 & RMNH.CRUS.D.57001 & Hilton Reef & $12.121789 \mathrm{~N}, 68.969508 \mathrm{~W}$ \\
\hline
\end{tabular}


RNA (16S rRNA) gene and the nuclear histone $H 3$ gene were obtained from anemone-associated $P$. rathbunae shrimp specimens and from the coral-associated resembling shrimps. Additional sequences were obtained from previous studies. By way of character based phylogenetic methods conducted in PAUP 4.0b10 (Swofford, 2002) and MrBayes 3.1.2 (Ronquist and Huelsenbeck, 2003), COI, $16 S$ and $H 3$ single-gene phylogenies were reconstructed to infer 1) if the coral-associated specimens belong to a novel, cryptic species of Periclimenes; or 2) if the specimens belong to the species Periclimenes rathbunae, indicating D. cylindrus is a new host of P. rathbunae. Beside P. rathbunae, the two other anemone-associated species Periclimenes yucatanicus (Ives, 1891) and Ancylomenes pedersoni (Chace, 1958) were added to infer their phylogenetic relations (see supplementary video S1). The sea urchin-associated Gnathophylloides mineri Schmitt, 1933 and ascidian associated Ascidonia quasipusilla (Chace, 1972) were included as outgroups in the analyses.

\section{Material and methods}

\section{Sampling}

Shrimps were collected at eight locations near the coast of Curaçao and preserved in ethanol (80\%). Photographs and videos were taken with a Nikon D80 digital photo camera and GoPro Hero 4 Silver video camera with a MacroMate Mini $55 \mathrm{~mm}+15$ close-up lens respectively. Eggs or pleopods were collected from 14 shrimps selected for DNA analyses of partial COI, $16 S$ and $H 3$ sequences (Table 1). Material has been deposited in Naturalis Biodiversity Center (formerly Rijksmuseum van Natuurlijke Historie, RMNH) and the Oxford University Museum of Natural History (OUMNH).

\section{Morphological analysis}

A detailed morphological description of the coral-associated specimens was made (Appendix) and compared with anemone-associated specimens. Drawings were made using a Zeiss Discovery.V8 and an Olympus BX53 stereo microscope, both with a drawing tube. Drawings were mounted using Adobe Photoshop CS6 software.

\section{DNA extraction}

Total genomic DNA was extracted with the NucleoMag® 96 Tissue kit (Machery-Nagel, Düren, Germany) using a Thermo Scientific KingFisher ${ }^{\mathrm{TM}}$ Flex Magnetic Particle Processor. Extraction was performed with $200 \mu 1$ lysis buffer and $20 \mu \mathrm{l}$ proteinase $\mathrm{K}$. Incubation took place overnight at $56^{\circ} \mathrm{C}$.

\section{Polymerase chain reaction}

Partial COI, $16 \mathrm{~S}$ and $\mathrm{H} 3$ sequences were amplified by polymerase chain reactions (PCR) in a total reaction

accession numbers. * the corresponding shrimp specimen was collected near this probable host.

\section{GenBank accession \#}

\author{
Host class: subclass: order: species
}

Anthozoa: Hexacorallia: Actiniaria: Condylactis gigantea* Anthozoa: Hexacorallia: Actiniaria: Bartholomea annulata * Anthozoa: Octocorallia: Holaxonia: Eunicia sp.

Anthozoa: Hexacorallia: Actiniaria: Condylactis gigantea Anthozoa: Hexacorallia: Actiniaria: Stichodactyla heliantus Anthozoa: Hexacorallia: Actiniaria: Stichodactyla heliantus Anthozoa: Hexacorallia: Actiniaria: Condylactis gigantea Anthozoa: Hexacorallia: Scleractinia: Dendrogyra cylindrus Anthozoa: Hexacorallia: Scleractinia: Dendrogyra cylindrus Anthozoa: Hexacorallia: Scleractinia: Dendrogyra cylindrus Anthozoa: Hexacorallia: Scleractinia: Dendrogyra cylindrus Anthozoa: Hexacorallia: Scleractinia: Dendrogyra cylindrus Echinoidea: Euechinoidea: Camarodonta: Lytechinus variegates Ascidiacea: - : Stolidobranchia: Pyura torpida (Sluiter, 1898)

\section{COI}

KX090106

KX090107

KX090108

KX090109

KX090110

KX090111

KX090112

KX090113

KX090114

KX090115

KX090116

KX090117

KX090118

KX090119
$16 S$

KX090083

KX090084

KX090085

KX090086

KX090087

KX090088

KX090089

KX090090

KX090091

KX090092

KX090093

KX090094

KX090095

KX090096
H3

KX090129
KX090130
KX090131
KX090132
KX090133
KX090134
KX090135
KX090136
KX090137
KX090138
KX090139
KT224392
KX090140


Table 2. Primer information. * M13F primer tail, 5'-TGTAAAACGACGGCCAG-3'; M13R primer tail, 5'-CAGGAAACAGCTATGAC-3'.

\begin{tabular}{|c|c|c|c|}
\hline Primer name & Sequence ( 5 ' to 3 ') & Target gene & Reference \\
\hline M13F-LCOI1490* & TGTAAAACGACGGCCAGTGGTCAACAAATCATAAAGATATTGG & $\mathrm{COI}$ & Folmer et al. (1994) \\
\hline M13R-HCO2198* & CAGGAAACAGCTATGACTAAACTTCAGGGTGACCAAAAAATCA & $\mathrm{COI}$ & Folmer et al. (1994) \\
\hline M13F-LepF1 * & TGTAAAACGACGGCCAGTATTCAACCAATCATAAAGATATTGG & $\mathrm{COI}$ & Hebert et al. (2004) \\
\hline M13R-LepR1 $*$ & CAGGAAACAGCTATGACTAAACTTCTGGATGTCCAAAAAATCA & $\mathrm{COI}$ & Hebert et al. (2004) \\
\hline M13F-jgCO1490* & TGTAAAACGACGGCCAGTTITCIACIAAYCAYAARGAYATTGG & $\mathrm{COI}$ & Geller et al. (2013) \\
\hline M13R-jgCO2198* & CAGGAAACAGCTATGACTAIACYTCIGGRTGICCRAARAAYCA & $\mathrm{COI}$ & Geller et al. (2013) \\
\hline $16 \mathrm{SarF}$ & CGCCTGTTTATCAAAAACAT & $16 S$ & Palumbi et al. (1991) \\
\hline $16 \mathrm{Sbr}$ & CCGGTCTGAACTCAGATCACGT & $16 S$ & Palumbi et al.(1991) \\
\hline F1 & ATGGCTCGTACCAAGCAGACVGC & $H 3$ & Colgan et al. (1998) \\
\hline R1 & ATATCCTTRGGCATRATRGTGAC & $H 3$ & Colgan et al. (1998) \\
\hline
\end{tabular}

volume of $25 \mu \mathrm{l}$. Primer sequences are included in Table 2.

A $658 \mathrm{bp}$ fragment of the mitochondrial cytochrome c oxidase subunit I gene (COI) was amplified with M13F-LCOI1490 and M13R-HCO2198 universal DNA primers (Folmer et al., 1994) mixed with Lepidoptera M13F-LepF1 and M13R-LepR1 primers (Hebert et al., 2004) in an equal volume ratio (1:1). If the desired 658 bp COI fragment could not be amplified using the two above mentioned primer pairs (that is, for sample BW0010, BW0060 and BW1050), alternative M13F-jgLCO1490 and M13R-jgHCO2198 COI primers were used, redesigned by Geller et al. (2013). The PCR reaction was performed with $1.0 \mu$ l forward primer $(10 \mu \mathrm{mol} / \mathrm{l}), 1.0 \mu \mathrm{l}$ reverse primer $(10 \mu \mathrm{mol} / \mathrm{l})$, $0.5 \mu \mathrm{l} \mathrm{dNTP}(2.5 \mathrm{mM})$ (Ammersham), $0.25 \mu \mathrm{l} \mathrm{Taq}$ DNA polymerase (5 U/ $\mu$ l) (QIAGEN), $2.5 \mu$ l CoralLoad 10x PCR buffer (QIAGEN) and 1-2 $\mu 1$ template DNA. The reaction mixtures of sample BW0010, BW0060 and BW1050 included $2.0 \mu$ l template DNA. The rest of the reactions were performed using $1.0 \mu 1$ template DNA. Initial denaturation took place for 3 minutes at $94^{\circ} \mathrm{C}$, followed by 39 cycles of denaturation, annealing and extension $\left(15\right.$ seconds at $94^{\circ} \mathrm{C} ; 30$ seconds at $50^{\circ} \mathrm{C}$ and 40 seconds at $72^{\circ} \mathrm{C}$ respectively). Final extension was performed for 5 minutes at $72^{\circ} \mathrm{C}$.

A $500-520 \mathrm{bp}$ fragment of the $16 \mathrm{~S}$ mitochondrial ribosomal gene was amplified with 16Sar and 16Sbr rDNA primers (Palumbi et al., 1991). The PCR reaction was performed with $1.0 \mu \mathrm{l}$ forward primer (10 $\mu \mathrm{mol} / \mathrm{l}), 1.0 \mu \mathrm{l}$ reverse primer $(10 \mu \mathrm{mol} / \mathrm{l}), 2.5 \mu \mathrm{ldNTP}$ (2.5 mM) (Ammersham), $0.25 \mu \mathrm{l} \mathrm{Taq} \mathrm{DNA} \mathrm{polymer-}$ ase (5 U/ $\mu \mathrm{l})$ (QIAGEN), $2.5 \mu \mathrm{l}$ CoralLoad 10x PCR buffer (QIAGEN) and $1 \mu 1$ template DNA. The reac- tion mixture of samples BW0010, BW0170, BW0171, BW0190 and BW1200 included 5.0 $\mu \mathrm{l}$ 5x Q-solution (QIAGEN). Initial denaturation took place for $3 \mathrm{~min}-$ utes at $94^{\circ} \mathrm{C}$, followed by 39 cycles of denaturation, annealing and extension $\left(10\right.$ seconds at $94^{\circ} \mathrm{C} ; 1$ minute at $50^{\circ} \mathrm{C}$ and 1 minute at $72^{\circ} \mathrm{C}$ respectively). Final extension was performed for 5 minutes at $72^{\circ} \mathrm{C}$. Annealing temperature of sample BW0010, BW0170, BW0171, BW0190 and BW1200 was set to $57^{\circ} \mathrm{C}$ to increase annealing specificity.

A $328 \mathrm{bp}$ fragment of the nuclear histone $\mathrm{H} 3$ (H3) gene was amplified with a F1 and R1 primer pair (Colgan et al., 1998). The PCR reaction was performed with $1 \mu \mathrm{l}$ forward primer $(10 \mu \mathrm{mol} / \mathrm{l}), 1 \mu \mathrm{l}$ reverse primer $(10 \mu \mathrm{mol} / \mathrm{l}), 2.5 \mu \mathrm{l} \mathrm{dNTP}(2.5 \mathrm{mM})$ (Ammersham), $0.25 \mu 1$ Taq DNA polymerase (5 U/ $\mu 1$ ) (QIAGEN), $2.5 \mu$ l CoralLoad 10x PCR buffer (QIAGEN) and $1 \mu \mathrm{l}$ template DNA. The reaction mixture of sample BW0190 included 5.0 $\mu 1$ 5x Q-solution (QIAGEN). Initial denaturation took place for 3 minutes at $95^{\circ} \mathrm{C}$, followed by 39 cycles of denaturation, annealing and extension $\left(10\right.$ seconds at $95^{\circ} \mathrm{C} ; 1$ minute at $48^{\circ} \mathrm{C}$ and 1 minute at $72^{\circ} \mathrm{C}$ respectively). Final extension was performed for 5 minutes at $72^{\circ} \mathrm{C}$.

\section{Sequencing}

Raw PCR products were purified, diluted and sequenced by BaseClear, Leiden. Sanger sequences were obtained with an ABI3730xl DNA Analyzer. M13F and M13R primers were used by BaseClear to sequence $\mathrm{COI}$ fragments. For sequencing of $16 \mathrm{~S}$ and $\mathrm{H3}$ gene fragments, the same primers as those that were used for PCR were supplied at a concentration of 5.0 pmole/ $\mu$ l. 


\section{Molecular phylogenetic analyses}

Of the 14 specimens selected for this study, $14 \mathrm{COI}$ sequences, $1416 \mathrm{~S}$ sequences and $13 \mathrm{H3}$ sequences were obtained (Table 1). Chromatograms were corrected manually using Sequencher (v. 4.10.1) and aligned using ClustalW Multiple alignment (v.1.4.; Thompson et al., 1994) with a gap open penalty of 15 and a gap extension penalty of 6.66. Nine $\mathrm{COI}$ sequences, nine $16 \mathrm{~S}$ sequences, and four $\mathrm{H3}$ sequences derived from Naturalis Biodiversity Center (Table 3, placed in Appendix) were added to the alignment. Gnathophylloides mineri Schmitt, 1933 (BW1050) was selected as outgroup in relation to the anemoneand scleractinian-associated species. To explore the effect of choosing a more closely related outgroup, Ascidonia quasipusilla (Chace, 1972) was selected alternatively. Sequences were trimmed to the length of the shortest sequence included in the alignment. All $\mathrm{COI}$ sequences comprised 658 bp. $16 \mathrm{~S}$ fragment length ranged from 506 to 509 bp. Partial H3 sequences included $328 \mathrm{bp}$. Stop codons were assumed to indicate pseudogenes had been sequenced. To verify no stop codons were included, $\mathrm{COI}$ alignments were translated using an invertebrate mitochondrial genetic code. $\mathrm{H3}$ sequences were translated with a standard genetic code. None of the $\mathrm{COI}$ and $\mathrm{H} 3$ sequences coded for stop codons. The single-gene alignment based on sequence data derived from the mitochondrial gene encoding cytochrome c oxidase subunit I (COI) comprised 21 ingroup sequences and one outgroup sequence. With outgroup G. mineri (BW1050), 204 characters of the 632 sites included in this alignment were variable, whereas 149 sites were parsimony informative. The $16 S$ ribosomal RNA single-gene alignment of 23 ingroup sequences and one outgroup sequence comprised 513 characters, 132 of which were variable. Seventy-nine sites were parsimony informative. The 276 bp histone 3 (H3) single-gene alignment contained 15 ingroup sequences and one outgroup sequence. Only 12 out of 50 variable sites were parsimony informative. $\mathrm{COI}$ and $\mathrm{H} 3$ alignments did not include any indels. Prior to submission to GenBank, the first base pair at the 5' end of the $\mathrm{COI}$ and the $\mathrm{H} 3$ sequences was removed to adjust the reading frame to reading frame 1.

The best-fitting models for sequence evolution of the COI (GTR+I), 16S (GTR+G) and H3 (GTR+I) datasets were determined by jModelTest 2.3.1. (Darriba et al., 2012), selected by the AIC (Akaike Information Criterion), and subsequently applied to the maxi- mum likelihood (ML) analyses with PAUP* $4.0 \mathrm{~b} 10$ (Swofford, 2003). ML trees were constructed using a heuristic search with tree-bisection-reconnection (TBR) branch-swapping algorithm. For ML analyses, tree reliability was estimated with a bootstrap test of phylogeny comprising 1000 replications. All codon positions, as well as non-coding sites, were examined. Gaps and missing data were ignored.

Bayesian inferences were estimated in MrBayes 3.1.2 (Ronquist and Huelsenbeck, 2003). The programme was run for $5,000,000$ generations with a burnin set to $25 \%$ for each marker using the most complex GTR+I+G model.

\section{Results}

\section{Morphological comparison}

A detailed morphological comparison revealed no characters that were different between coral- and anemone-associated specimens. Distinguishing characters in the genus Periclimenes, like the shape of the rostrum (Fig. 4C-K) and features on the dactyli of the ambulatory pereiopods (Figs. 9, 10), are identical among coral- and anemone-associated specimens. The maximum size of specimens on the stony coral host is much smaller than that of specimens collected from sea anemones, pocl. $2.58 \mathrm{~mm}$ versus pocl. $5.25 \mathrm{~mm}$ respectively. The median size of stony coral-associated specimens ( $\mathrm{pocl}=1.88 \mathrm{~mm} ; \mathrm{n}=11)$ is significantly smaller than that (pocl $=2.60 \mathrm{~mm} ; \mathrm{n}=50)$ of $P$. rathbunae collected from anemones (Wilcoxon rank sum test, $\mathrm{p}<0.001)$. The size of ovigerous females ranges from pocl. 1.78-2.58 in the stony coral associates and between 2.05-5.25 in anemone-associated specimens.

Phylogenetic position of the coral-associated specimens

ML trees based on COI, $16 \mathrm{~S}$ and $\mathrm{H} 3$ sequence data are presented in Fig. 2A-C respectively. Both anemoneand stony coral-associated Periclimenes rathbunae specimens formed a highly supported monophyletic clade. Branching within this clade was poorly supported.

The selection of Gnathophylloides as outgroup affected the branching order of clade 1 (Periclimenes rathbunae and coral-associated Periclimenes), clade 2 (Ancylomenes pedersoni), and clade 3 (Periclimenes yucatanicus) of Fig. 2. When Ascidonia quasipusilla 

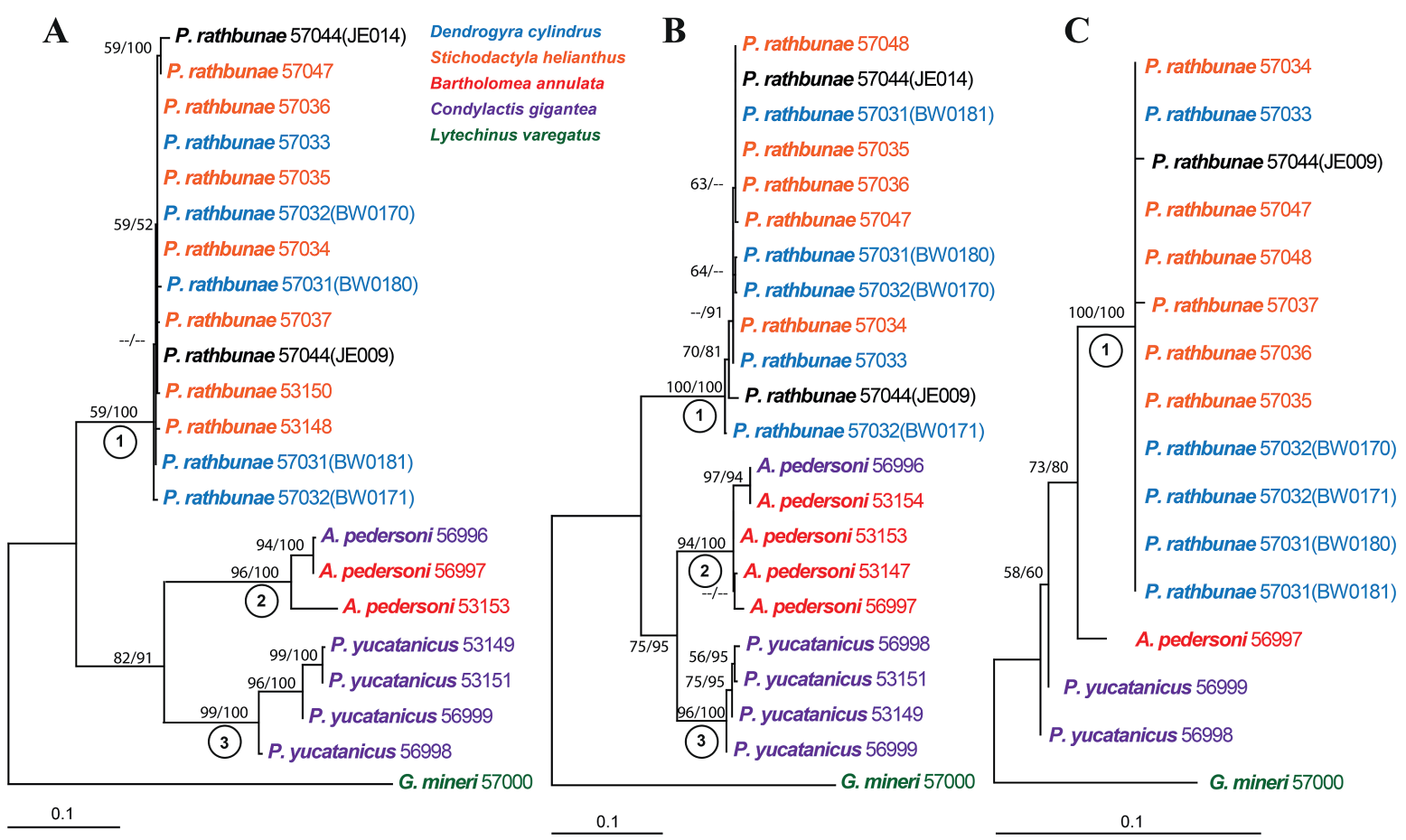

Fig. 2. Maximum likelihood (ML) trees. Confidence values at the nodes were obtained from 1000 bootstrap replicates of ML trees (first number) and Bayesian Inference (BI) (second number). Only values above 50\% are indicated. Scale bars indicate genetic distance. Colours correspond to host species.

(BW1200) was selected alternatively, either Ancylomenes pedersoni (in $\mathrm{COI}$ and $\mathrm{H} 3 \mathrm{ML}$ phylogenetic reconstructions) or P. yucatanicus (in a $16 S$ ML phylogenetic reconstruction) branched off first, followed by the remaining two species branching off as sister species. However, independent of the chosen outgroup, support for clade 1 was high, while branching support within the clade remained poor.

\section{Discussion and conclusions}

Phylogenetic reconstructions based on partial COI, $16 \mathrm{~S}$ and $\mathrm{H3}$ sequences clustered the coral-associated Periclimenes and Periclimenes rathbunae within one clade with very high to maximal statistical support (Fig. 2). This shows that the specimens of coral-associated Periclimenes belong to $P$. rathbunae.

The association of $P$. rathbunae with Dendrogyra cylindrus identified here is the first report of a scleractinian coral associating with an Atlantic palaemonid shrimp species. While colonies of D. cylindrus consti- tute up to $3 \mathrm{~m}$ high, cylindrical pillars, anemones that typically host $P$. rathbunae, like Bartholomea апnиlata (known as 'ringed anemone' or 'corkscrew anemone') and Stichodactyla helianthus (descriptively named 'Caribbean carpet anemone'), extent no more than approximately $20 \mathrm{~cm}$ from the sea floor. Despite this clear difference in the overall shape of both hosts, the surface structure of $D$. cylindrus, comprising relatively long undulating tentacles standing out during daytime, is remarkably similar to that of anemones. Likewise, soft coral Eunicea tourneforti and corallimorph Ricordea florida, which have also been found to host $P$. rathbunae (Ritson-Williams and Paul, 2007; Hayes and Trimm, 2008), are covered with tentacles, suggesting a surface with tentacles, or at least tentacle-like extensions, is essential to the habitat of $P$. rathbunae.

Hosted by anemones, adult $P$. rathbunae have an orange dominated colour pattern, whereas the species is more translucent with a more olive colour pattern when it is hosted by D. cylindrus. Similar colour transformations have been reported to result from centrip- 
etal and centrifugal pigment translocation in the cytoplasm of specialised shrimp cells called chromatophores (Fingerman, 1970), located at the skin and at the surface of internal organs. This has been found to enable rapid colour changes, allowing for adaptive processes including camouflaging, aposematic signalling and intraspecific communication (Milograna et al., 2012).

Spotte et al. (1991) already noticed that P. rathbunae is able to alter its transparency to adapt its colouration to that of the host. Shrimps collected from Stichodactyla helianthus, that were observed in vitro, had a less intense olive colour than the shrimps occurring in nature. Specimens inhabiting Condylactis gigantea didn't have any background colouration. Spotte et al. (1991) concluded such transparency allows light from the surface of the anemone to be transmitted through the shrimp body, thereby matching its overall colouration to that of the variably coloured hosts. Moreover, Spotte et al. (1991) described the colouration of $P$. rathbunae is age-depended, with juveniles having an overall clear appearance. In addition to the median size of the shrimp specimens collected from D. cylindrus, which was smaller than that of specimens collected from anemones, this suggests $D$. cylindrus hosts more juvenile $P$. rathbunae.

Baeza et al. (2001) observed a comparable distribution of the commensal crab Allopetrolisthes spinifrons (H. Milne Edwards, 1837) among its hosts. A. spinifrons has been documented to associate with sea anemones, gastropods and sea stars. Whereas small life stages of the crab were found to inhabit all of these hosts, adult (mature) crabs were only hosted by sea anemones. Baeza et al. (2001) expected habitat restrictions force A. spinifrons larvae to settle on alternative non-anthozoan hosts (gastropods and sea stars) that offer protection against predation and possibly provide a food source (mucus) too. During ontogeny, juvenile crabs likely migrate to the preferred host (sea anemones) over short periods of time, resulting in the identified host-use pattern.

Despite the similarity in the host-use patterns of $A$. spinifrons and $P$. rathbunae, the same reasoning cannot fully explain the distribution of $P$. rathbunae between its anemone and stony coral hosts. Beside the small translucent specimens of $P$. rathbunae (probably juvenile shrimps), also ovigerous females were collected from the stony coral host (Table 1). This shows the guest range of $D$. cylindrus is not completely restricted to small juvenile (immature) life stages of $P$. rathbunae. Moreover, in contrast to the anemone hosts of A. spinifrons, that usually host no more than one adult or juvenile crab (Baeza et al., 2001), one anemone can be inhabited by numerous conspecific shrimps. This reduces the probability that habitat (host availability) restrictions occur for P. rathbunae in nature, as one host is not fully occupied by the time one, or a few individuals have settled on the host.

Although several studies have questioned (Baeza et al., 2001) or investigated (Levine and Blanchard, 1980; Crawford, 1992; Giese et al., 1996) the effect of sea anemone toxins on their decapod inhabitants, the sensitivity to sea anemone nematocysts has not been linked to host-use patterns before. However, the effect of sea anemones on their inhabitants, which varies between different species of anemones and their inhabitants (Levine and Blanchard, 1980; Elliot and Mariscal, 1996), shows some potential to facilitate ontogenetic habitat-shifts. Levine and Blanchard (1980) found unacclimated shrimps of $P$. rathbunae that have just moulted are more vulnerable to stinging nematocysts than conspecific shrimps that did not moult prior to the exposure to the anemone (S. helianthus). As moulting is required for the growth of (juvenile) shrimps, this might explain why juvenile shrimps occur on alternative, less aggressive hosts like $D$. cylindrus. To test any of these hypotheses, further in-depth field ecological studies for this species will be needed.

\section{Acknowledgements}

Special thanks go to Sancia E.T. van der Meij for discovering and collecting the coral-associated specimens of Periclimenes rathbunae, and for the identification of the scleractinian host coral. We wish to acknowledge the supervision provided by Kevin Beentjes at the barcoding lab. Advice and primers provided by Bastian T. Reijnen were greatly appreciated. Nicolette Snijders, Bardo Cornelder and Joni Eilbracht are acknowledged for sequencing specimens. Jaap de Vries provided video footage of shrimps and hosts. The comments of two anonymous reviewers greatly improved the manuscript. We are grateful to the Jan Joost ter Pelkwijk Fonds and L.B. Holthuis Fonds for funding. DNA barcodes were obtained within the framework of the Barcoding Project: Barcoding of Crustacea (BCP0013).

\section{References}

Baeza JA, Stotz W, Thiel M. 2001. Life history of Allopetrolisthes spinifrons, a crab associate of the sea anemone Phymactis clematis. Journal of the Marine Biological Association of the United Kingdom 80: 69-76. doi.org/10.1017/ S0025315401003411 
Bickford D, Lohman DJ, Sdohi NS, Ng PKL, Meier R, Winker K, Ingram KK, Das I. 2006. Cryptic species as a window on diversity and conservation. Trends in Ecology and Conservation 22: 148-155.

Bruce AJ. 2007. A re-definition of the genus Periclimenes Costa, 1844 and the designation of a new genus Margitonia (Crustacea: Decapoda: Pontoniinae). Cahiers de Biologie Marine 48: 403-406.

Carlgren O. 1900. Ostafrikanische Actinien. Mitteilungen aus dem Naturhistorischen Museum, Hamburg 17: 21-144.

Chace FAJr. 1958. A new shrimp of the genus Periclimenes from the West Indies. Proceedings of the Biological Society of Washington 71: 125-130.

Chace, FAJr. 1972. The shrimps of the Smithsonian-Bredin Caribbean expeditions with a summary of the West Indian shallow-water species (Crustacea: Decapoda: Natantia). Smithsonian Contributions to Zoology 98: 1-179.

Colgan DJ, McLauchlan A, Wilson GDF, Livingston SP, Edgecombe GD, Macaranas J, Cassis G, Gray MR. 1998. Histone H3 and U2 snRNA DNA sequences and arthropod molecular evolution. Australian Journal of Zoology 46: 419-437.

Costa OG. 1844. Su due nuovi generi di Crostacei decapodi macrouri. Annali delle Accademia degli Apiranti Naturalisti, Napoli 2: 285-292.

Crawford JA. 1992. Acclimation of the shrimp, Periclimenes anthophilus, to the giant sea anemone, Condylactis gigantea. Bulletin of Marine Science 50: 331-341.

Darriba D, Taboada GL, Doallo R, Posada D. 2012. jModeltest 2: more models, new heuristic and parallel computing. $\mathrm{Na}$ ture Methods 9: 772.

De Grave S. 2014. A new species of crinoid-associated Periclimenes from Honduras (Crustacea: Decapoda: palaemonidae). Zootaxa 3793: 587-594.

De Grave S, Fransen CHJM. 2011. Carideorum catalogus: the recent species of the dendrobranchiate, stenopodidean, procarididean and caridean shrimps (Crustacea: Decapoda). Zoologische Mededelingen Leiden 85: 195-589.

Duchassaing de Fonbressin EP, Michelotti G. 1860. Mémoire sur les coralliaires des Antilles. Imprimerie Royale, Turin.

Ehrenberg CG. 1834. Beitrage zur physiologischen Kenntniss der Corallenthiere im Allgemeinen und besunders des Rothen Meeres, nebst einem Versuche zur physiologischen Systematik derselben. Abhandlungen der Königlichen Akademie der Wissenschaften, Berlin 1832: 225-380.

Elliot JK, Mariscal RN. 1996. Ontogenetic and interspecific variation in the protection of anemonefishes from sea anemones. Journal of Experimental Marine Biology and Ecology 208: 57-72.

Ellis J. 1768. An Account of the Actinia Sociata, or Clustered Animal-Flower, Lately Found on the Sea-Coasts of the New-Ceded Islands: In a Letter from John Ellis, Esquire, F. R. S. to the Right Honourable the Earl of Hillsborough, F. R. S. In: Philosophical Transactions, 57 [for 1767]: 428-437, 434-435.

Fingerman M. 1970. Comparative physiology: chromatophores. Annual Review of Physiology 32: 345-372.

Folmer O, Black M, Hoeh W, Lutz R, Vrijenhoek R. 1994. DNA primers for amplification of mitochondrial cytochrome $\mathrm{c}$ oxidase subunit I from diverse metazoan invertebrates. Molecular Marine Biology and Biotechnology 3: 294-299.
Geller J, Meyer C, Parker M, Hawk H. 2013. Redesign of PCR primers for mitochondrial cytochrome c oxidase subunit I for marine invertebrates and application in all-taxa biotic surveys. Molecular Ecology Resources 13: 851-861.

Giese C, Mebs D, Werding B. 1996. Resistance and vulnerability of crustaceans to cytolytic sea anemone toxins. Toxicon 34: 955-958.

Hayes FE, Trimm NA. 2008. Distributional ecology of the anemone shrimp Periclimenes rathbunae associating with the sea anemone Stichodactyla helianthus at Tobago, West Indies. Nauplius 16: 73-77.

Hebert PDN, Penton EH, Burns JM, Janzen DH, Hallwachs W. 2004. Ten species in one: DNA barcoding reveals cryptic species in the neotropical skipper butterfly Astraptes fulgerator. Proceedings of the National Academy of Science of the United States of America 101: 14812-14817.

Holthuis LB. 1951. A general revision of the Palaemonidae (Crustacea Decapoda Natantia) of the Americas. I. The subfamilies Euryrhynchidae and Pontoniinae. Occasional Papers of the Allan Hancock Foundation 11: 1-332.

Ives JE. 1891. Crustacea from the northern coast of Yucatan, the harbor of Vera Cruz, the west coast of Florida and the Bermuda Islands. Proceedings of the Academy of Natural Sciences of Philadelphia 1891: 176-207.

Kingsley JS. 1879. List of the North American Crustacea belonging to the suborder Caridea. Bulletin of the Essex Institute 10 [for 1878]: 53-71.

Knowlton N. 1993. Sibling species in the sea. Annual Review of Ecology and Systematics 24: 189-216.

Knowlton N. 2000. Molecular genetic analyses of species boundaries in the sea. Hydrobiologia 420: 73-90.

Le Sueur CA. 1817. Observations on several species of the genus Actinia; illustrated by figures. Journal of the Academy of Sciences of Philadelphia 1: 149-154, 169-189.

Levine DM, Blanchard OJ. 1980. Acclimation of two shrimps of the genus Periclimenes to sea anemones. Bulletin of Marine Science 30: 460-466.

Milne Edwards H. 1836-1844. Les Crustaés. In: Cuvier G, Le Règne Animal distribué d'après son organization, pour server de base à l'histoire des animaux, et d'introduction à l'anatomie comparée, ed. 4: vol. 17 (text): 1-278; vol. 18 (atlas): plates 1-80. Paris.

Milne Edwards H, Haime J. 1857. Histoire naturelle des coralliaires ou polypes proprement dits, Vol. 1 pp. i-xxxiv + 1-326, 8 plates, numbered A1-6, B1-2. Paris, à la Libraire Encyclopédique de Roret.

Milograna SR, Bell FT, McNamara JC. 2012. Signaling events during cyclic guanosine monophosphate-regulated pigment aggregation in freshwater shrimp chromatophores. The Biological Bulletin 2: 178-191.

Mitsuhashi M, Li X, Chan T-Y. 2012. Additional deep-sea pontoniine shrimps (Decapoda: Palaemodidae) from Taiwan, with description of one new species. In: Komatsu H, Okuno J, Fukuoka K. (eds.), Studies on Eumalacostraca: a homage to Masatsune Takeda. Crustaceana Monographs 17: 211-213.

Palumbi S, Martin A, Romano S. 1991. The Simple Fool's Guide to PCR. Department of Zoology and Kewalo Marine Laboratory, University of Hawaii: Honolulu, Hawaii.

Posada D. 2008. jModelTest: Phylogenetic Model Averaging. Molecular Biology and Evolution 25: 1253-1256. 
Rafinesque CS. 1815. Analyse de la Nature ou Tableau de l'Univers et des corps organisé: 1-224. Palerme.

Ritson-Williams R, Paul VJ. 2007. Periclimenes yucatanicus and Periclimenes rathbunae on unusual corallimorph hosts. Coral Reefs 26: 147.

Ronquist F, Huelsenbeck JP. 2003. MRBAYES 3: Bayesian phylogenetic inference under mixed models. Bioinformatics 19: 1572-1574.

Rüppell E, Leuckart FS. 1828. Atlas zu der Reise im Nördlichen Afrika von Eduard Rüppell, Neue Wirbellose Thiere des Rothen Meers. Frankfurt, H.L. Brönner pp. 1-22, pl. 1-12.

Saville-Kent W. 1893. The Great Barrier Reef of Australia; Its Products and Potentialities. London, W.H. Allen pp. 1-387, pls. 1-48, chromo pls. 1-16.

Schmitt WL. 1924. Bijdrage tot de kennis der fauna van $\mathrm{Cu}-$ raçao. Resultaten eener reis van Dr. C.J. van der Horst in 1920. The macruran, anomuran and stomatopod Crustacea. Bijdragen tot de Dierkunde 23: 61-81.

Schmitt WL. 1933. Four new species of decapod crustaceans from Porto Rico. American Museum Novitates 662: 1-9.

Spotte S, Heard RW, Bubucis PM, Manstan RR, McLelland JA. 1991. Pattern and coloration of Periclimenes rathbunae from the Turks and Caicos Islands, with comments on host associations in other anemone shrimps of the West Indies and Bermuda. Gulf Research Reports 8: 301-311.

Swofford DL. 2002. PAUP*. Phylogenetic Analysis Using Parsimony (*and Other Methods). Version 4. Sunderland, Massachusetts, Sinauer Associates pp. i-ii, 1-128.

Thompson JD, Higgins DG, Gibson TJ. 1994. CLUSTAL W: improving the sensitivity of progressive multiple sequence alignment through sequence weighting, position-specific gap penalties and weight matrix choice. Nucleic Acids Research 22: 4673-4680.

Verrill AE. 1864. Revision of the Polypi of the eastern coast of the United States. Memoirs of the Boston Society of Natural History 1: 1-45.

Weinland DF. 1860. Über Inselbildung durch Korallen und Mangrovebüsche im mexikanischen Golf. Württembergische Naturwissenschaftlichen Jahrhefte 16: 31-44.

Received: 21 July 2015

Revised and accepted: 12 May 2016

Published online: 15 November 2016

Editor: R. Vonk

\section{Online supplementary information}

S1. Palaemonid shrimps on diverse hosts. In chronological order: Periclimenes rathbunae on Dendrogyra cylindrus, Periclimenes rathbunae on Stichodactyla helianthus, Periclimenes yucatanicus on Condylactis gigantea, Ancylomenes pedersoni on Bartholomea annulata and Gnathophylloides mineri on Lytechinus variegatus. 


\section{Appendix}

\section{Systematic account}

Family Palaemonidae Rafinesque, 1815

Genus Periclimenes Costa, 1844

Periclimenes rathbunae Schmitt, 1924

(Figs. 1, 3-11)

Periclimenes rathbunae Schmitt, 1924: 70, Figs. 5-6; Holthuis, 1951: 58, pl. 17.

Type-locality. Spanish Port, Curaçao, Netherlands Antilles.

\section{Holotype. ZMA DE240829}

Material examined. Netherlands Antilles, Curaçao. Holotype female (pocl. 3.25 mm), ZMA DE240829: Spanish Port, 20.v.1920, collected by C.J. van der Horst.- 2 ovigerous females (pocl. 1.78, $2.18 \mathrm{~mm}$ ), 3 non-ovigerous females (pocl. 1.43, 1.57, $1.60 \mathrm{~mm}$ ), RMNH.CRUS.D.57031: stn COA.21, Marie Pampoen, N 12.090761 W 68.904956, 5.xi.2013, depth 10 m, on Dendrogyra cylindrus Ehrenberg, 1834, collected by S.E.T. van der Meij, photo COA.21 041-052.- 2 ovigerous females (both pocl. $1.88 \mathrm{~mm}$ (drawings)) OUMNH.ZC.2015-02-008, 1 ovigerous female (pocl. 2.13 mm), 1 male (pocl. $1.63 \mathrm{~mm}$ ), RMNH.CRUS.D.57032: stn COA.17, Cas Abou, N 12.227861 W 69.091778, 3.xi.2013, depth 8 m, on Dendrogyra cylindrus Ehrenberg, 1834, collected by S.E.T. van der Meij, photo COA.17 020-025. - 2 ovigerous females (pocl. 2.06, $2.58 \mathrm{~mm}$ ), RMNH.CRUS.D.57033: COA.22, Grote Knip, N 12.351139 W 69.151917, 6.xi.2013, depth 8 m, on Dendrogyra cylindrus Ehrenberg, 1834, collected by C.H.J.M. Fransen, photo COA.22 223-237.- 1 male (pocl. $2.50 \mathrm{~mm}, \mathrm{P} 2 \mathrm{major}$ regenerating), 1 female (pocl. $1.55 \mathrm{~mm}$ ) RMNH.CRUS.D.57034: stn COA.01, Hilton Reef, N 12.121789 W 68.969508, 31.x.2013, depth 20 m; on Stichodactyla helianthus (Ellis, 1768), collected by C.H.J.M. Fransen, photo COA.01 071081.- 1 ovigerous female (pocl. $2.51 \mathrm{~mm}$ ) RMNH. CRUS.D.57035: stn COA.18, Playa Forti, N 12.366139 W 69.15375, 1.xi.2013, depth 15 m, on Condylactis gigantea (Weinland, 1860), collected by C.H.J.M. Fransen, photo COA.18 026-032.- 1 ovigerous female (pocl. $4.75 \mathrm{~mm}$ ), RMNH.CRUS.D.57036: stn COA.05, Car Wrecks, N 12.161 W 69.004083, 3. xi.2013, on Stichodactyla helianthus (Ellis, 1768), collected by C.H.J.M. Fransen, photo COA.05 038-053.1 female (pocl. $3.35 \mathrm{~mm}$ ), 1 male (pocl. $1.65 \mathrm{~mm}$ )
RMNH.CRUS.D.57037: CUR.01, south coast, Carmabi Reef/Hilton Pier, $12^{\circ} 16^{\prime} 19.2^{\prime \prime N} 068^{\circ} 58^{\prime} 09.0^{\prime \prime} \mathrm{W}$, depth $5.1 \mathrm{~m}, 26 . i v .2005$, on Stichodactyla helianthus, collected by N. Snijders. g006.- 1 ovigerous female (pocl. $2.60 \mathrm{~mm}$ ) RMNH.CRUS.D.57038: CUR.01, south coast, Carmabi Reef/Hilton Pier, $12^{\circ} 16^{\prime} 19.2^{\prime \prime} \mathrm{N}$ $068^{\circ} 58^{\prime} 09.0^{\prime \prime} \mathrm{W}$, depth $8 \mathrm{~m}, 26 . i v .2005$, on Lebrunia neglecta, collected by N. Snijders. g007.- 1 non-ovigerous female (pocl. $2.35 \mathrm{~mm}$ ) RMNH.CRUS.D.53148: CUR.01: south coast, Carmabi Reef/Hilton Pier, $12^{\circ} 16^{\prime} 19.2^{\prime \prime} \mathrm{N} 068^{\circ} 58^{\prime} 09.0$ '”, depth 5.2 m, 26.iv.2005, on Stichodactyla helianthus, collected by N. Snijders. g014.- 1 non-ovigerous female (pocl. $2.75 \mathrm{~mm}$ ) RMNH.CRUS.D.53150: CUR.03: south coast, Hilton Reef, 1207'19.5'N 068 58'07.8'W, depth 5.3 m, 27. iv.2005, on Stichodactyla helianthus, collected by N. Snijders. g019.- 1 ovigerous female (pocl. $2.55 \mathrm{~mm}$ ) RMNH.CRUS.D.57039: CUR.03, south coast, Hilton Reef, $12^{\circ} 07^{\prime} 19.5^{\prime} \mathrm{N} 068^{\circ} 58^{\prime} 07.8^{\prime}$ W, depth 4 m, 27. iv.2005, on Stichodactyla helianthus, collected by N. Snijders. g020.- 2 females (pocl. 1.85 and $4.35 \mathrm{~mm}$ ) RMNH.CRUS.D.57040: CUR.03, south coast, Hilton Reef, 1207'19.5'N 068 $58^{\circ} 07.8^{\prime \prime} \mathrm{W}$, depth 4 m, 27. iv.2005, on Stichodactyla helianthus, collected by N. Snijders, g021.- 1 female (pocl. $2.70 \mathrm{~mm}$ ), 1 male (pocl. $1.80 \mathrm{~mm}$ ), RMNH.CRUS.D.57041: CUR.03, south coast, Hilton Reef, $12^{\circ} 07^{\prime} 19.5^{\prime \prime} \mathrm{N} 068^{\circ} 58^{\prime} 07.8^{\prime}$ 'W, depth 4 m, 27.iv.2005, on Stichodactyla helianthus, collected by N. Snijders, g022.- 1 female (pocl. 1.80 mm) RMNH.CRUS.D.57042: CUR.03, south coast, Hilton Reef, $12^{\circ} 07^{\prime} 19.5^{\prime}{ }^{\prime} \mathrm{N} 068^{\circ} 58^{\prime} 07.8^{\prime \prime} \mathrm{W}$, depth 2.9 m, 27.iv.2005, on Stichodactyla helianthus, collected by N. Snijders, g023. - 1 male (pocl. $2.40 \mathrm{~mm}$ ) RMNH.CRUS.D.57043: CUR.03, south coast, Hilton Reef, $12^{\circ} 07^{\prime} 19.5^{\prime}$ 'N $068^{\circ} 58^{\prime} 07.8^{\prime \prime} \mathrm{W}$, depth $2.3 \mathrm{~m}, 27$. iv.2005, on Stichodactyla helianthus, collected by N. Snijders. g028. -1 ovigerous female (pocl. $2.80 \mathrm{~mm}$ ) RMNH.CRUS.D.57044: CUR.05, south coast, Marie Pampoen/ Carpile, 1205'42.1”N 068 54 '43.0”W, depth $12 \mathrm{~m}, 1 . v .2005$, on Hexacorallia, collected by N. Snijders. g037, JE-009.- 4 females (pocl. 2.30, 3.85, 4.00 and $4.10 \mathrm{~mm}$ ) 1 male (pocl. $1.75 \mathrm{~mm}$ ) RMNH. CRUS.D.57045: CUR.01, south coast, Hilton pier, 12 07'19.2”N 068 58'09.0”W, 3.5 m depth, 2.v.2005, on Stichodactyla helianthus, collected by N. Snijders g042.- 1 ovigerous female (pocl. $2.05 \mathrm{~mm}$ ) RMNH. CRUS.D.57046: CUR.07, south coast, Vaersenbaai, $12^{\circ} 09^{\prime} 38.3^{\prime \prime} \mathrm{N} 069^{\circ} 08^{\prime} 17.2^{\prime} \mathrm{W}$, depth $5.5 \mathrm{~m}, 03 . \mathrm{v} .2005$, on Lebrunia neglecta, collected by N. Snijders. g044.- 


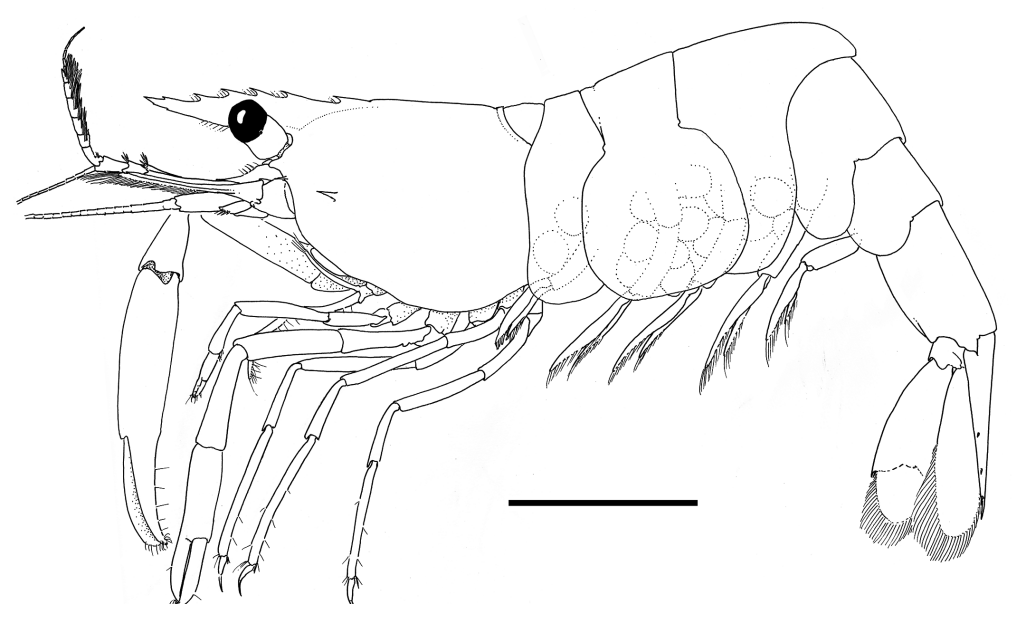

Fig. 3. Periclimenes rathbunae Schmitt, 1924. Ovigerous female, pocl. $2.18 \mathrm{~mm}$, RMNH.CRUS.D.57031, habitus, lateral view. Scale bar: $2 \mathrm{~mm}$.
1 non-ovigerous female (pocl. $4.05 \mathrm{~mm}$ ), RMNH. CRUS.D.57047: CUR.03, Hilton Reef, $12^{\circ} 07^{\prime} 19.5^{\prime \prime} \mathrm{N}$ 068 58'07.8”'W, 5.2 m depth, 13.v.2005, on Stichodactyla helianthus, collected by N. Snijders, g068.- 1 male (pocl. $1.95 \mathrm{~mm}$ ) RMNH.CRUS. D.57048: CUR.22, south coast, Superior Producer, $12^{\circ} 05^{\prime} 21.5^{\prime \prime} \mathrm{N}$ $068^{\circ} 56^{\prime} 35.5^{\prime \prime} \mathrm{W}$, depth 4.4 m, 2.vi.2005, on Stichodactyla helianthus, collected by N. Snijders. g094.- 1 male (pocl. $2.20 \mathrm{~mm}$ ), RMNH.CRUS. D.57049: CUR.22, South Coast, Superior Produces, $12^{\circ} 05^{\prime} 21.5^{\prime} \mathrm{N} 068^{\circ} 56^{\prime} 35.5^{\prime \prime} \mathrm{W}, 4.6 \mathrm{~m}$ depth, 2.vi.2005, on Stichodactyla helianthus, collected by N. Snijders, g097.- 1 ovigerous female (pocl. $3.00 \mathrm{~mm}$ ), 1 male (pocl. $1.75 \mathrm{~mm}$ ) RMNH.CRUS.D.37655: Piscadera baai, W side of mouth, between Rhizophora, 14.xii.1963, collected by P. Wagenaar Hummelinck, no. 1460.- 2 ovigerous females (pocl. 2.40, $3.30 \mathrm{~mm}$ ), 2 non-ovigerous females (pocl. 2.35, $2.45 \mathrm{~mm}$ ) RMNH. CRUS.D.37651: Piscadera baai, 25.vii.1978, on Bartholomea annulata, collected by Svoboda.- 2 ovigerous females (pocl. 4.60, $5.25 \mathrm{~mm}$ ), 3 non-ovigerous females (pocl. 2.60, 2.95, $3.25 \mathrm{~mm}$ ), 5 males (pocl. 1.45-2.35 mm) RMNH.CRUS.D.30617: Awa di Oostpunt, $1 \mathrm{~m}$ depth, 8.viii.1973, on Stoichactis sp. in Thalassia-bed, collected by J.C. den Hartog. - 4 ovigerous females (pocl. 3.35-4.40 mm) RMNH. CRUS.D.30616: Vaerssen Baai, 1.3-3 m, 25.iv.1973, on Stichodactyla helianthus, collected by J.C. den Hartog and R. de Windt. -1 female (pocl. $2.80 \mathrm{~mm}$ ), 2 males (pocl.1.80, $2.60 \mathrm{~mm}$ ) RMNH.CRUS.D.30618: Awa di Oostpunt, 1.5-3 m, 8.viii.1973, on Exaiptasia pallida, collected by J.C. den Hartog and R. de Windt. - 1 ovigerous female (pocl. $3.90 \mathrm{~mm}$ ) RMNH.CRUS.D.30619:
Vaerssen Baai, 1.5-3 m, 24.vii.1973, on Stichodactyla helianthus, collected by J.C. den Hartog and R. de Windt.- 3 females (pocl. 2.80-3.20 mm) RMNH. CRUS.D.26236a: summer 1968, on Lebrunia neglecta, collected by F. Nijhout.- 1 ovigerous female (pocl.3.50 mm), 1 female (pocl. $4.15 \mathrm{~mm}$ ) RMNH. CRUS.D.26236b: summer 1968, on Stichodactyla helianthus, collected by F. Nijhout. Bonaire. 2 ovigerous female (pocl. 3.25, $4.25 \mathrm{~mm}$ ) RMNH.CRUS.D.30620: off Goto Lake, in shallow water, 11.iv.1973, on Stichodactyla helianthus, collected by J.C. den Hartog. Virgin Islands. 1 female (pocl. $3.75 \mathrm{~mm}$ ) RMNH. CRUS.D.20809: Tavernier, -.ii.1971, collected by N. Ziler. Florida Keys, U.S.A. 1 ovigerous female (pocl. $3.00 \mathrm{~mm}$ ) RMNH.CRUS.D.20810: Lameshur Bay, St. John, 31.vii.1970, $30 \mathrm{ft}$ depth, on Bartholomea annulata, collected by R.H. Chesher.

Description. Small sized, rather slender shrimp, with slender pereiopods (Fig. 3).

Carapace smooth. Rostrum (Fig. 4A-K) well developed, reaching to end of basal segment of antennular peduncle; lamina deep, lateral carina indistinct, situated near to proximally slightly convex ventral margin with 0-3 (usually 1) very small subdistal teeth; convex posterior part of ventral margin with single row of plumose setae; dorsal margin convex, elevated, strongly compressed, with 5-8 subequal teeth, posteriormost one or two (seldom three) teeth situated posteriorly to level of posterior margin of orbit, proximalmost tooth usually at somewhat larger distance to anterior teeth than distance between teeth on rostrum proper; 2-3 plumose setae just in front of dorsal teeth. 


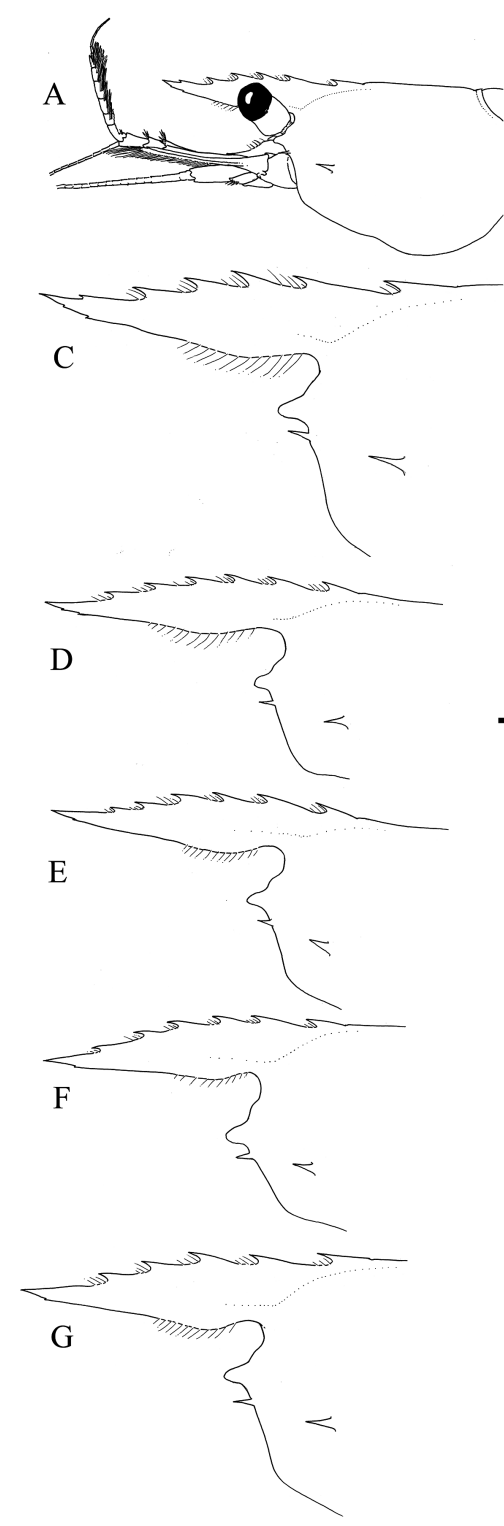

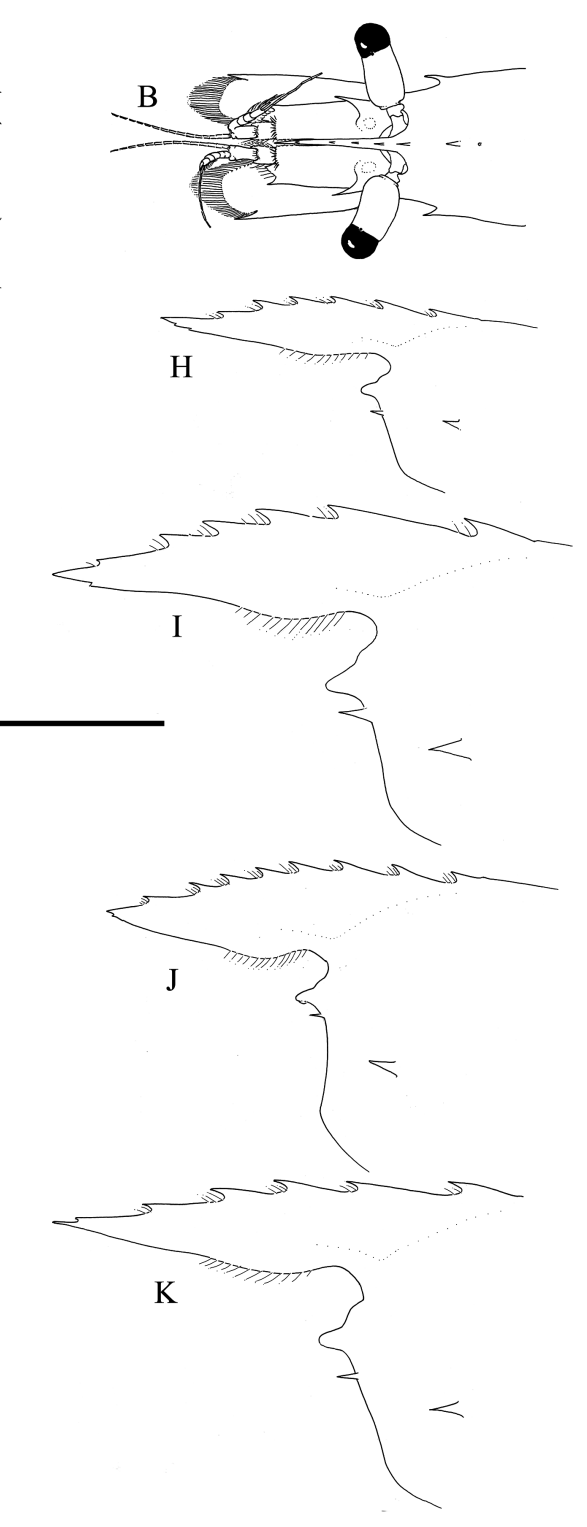

Fig. 4. Periclimenes rathbunae Schmitt, 1924. Ovigerous female, pocl. $2.18 \mathrm{~mm}$, RMNH.CRUS.D.57031: A, anterior appendages, lateral view; $\mathrm{B}$, anterior appendages, dorsal view. C-K, rostrum, lateral view; C-G, associated with Dendrogyra cylindrus Ehrenberg, 1834, RMNH.CRUS.D.57031; H-K, associated with Stichodactyla helianthus (Ellis, 1768). C, ovigerous female, pocl. 2.18 $\mathrm{mm}$; D, female pocl $1.60 \mathrm{~mm}$; E, female pocl $1.57 \mathrm{~mm}$; F, female pocl $1.43 \mathrm{~mm}$; $\mathrm{G}$, ovigerous female pocl. $1.78 \mathrm{~mm} ; \mathrm{H}$, female pocl. $1.55 \mathrm{~mm}$, RMNH. CRUS.D.57034; I, male pocl. $2.50 \mathrm{~mm}$, RMNH.CRUS.D.57034; J, ovigerous female pocl $4.75 \mathrm{~mm}$, RMNH. CRUS.D.57036; K, ovigerous female pocl. $2.51 \mathrm{~mm}$, RMNH.CRUS.D.57035. Scale bar: A, B, J = $2 \mathrm{~mm}$; C-I, K = $1 \mathrm{~mm}$.
Supra-orbital spines absent. Inferior orbital angle well developed, produced, rounded in lateral view. Antennal spine small, marginal, situated below inferior orbital angle. Hepatic spine distinctly larger than antennal spine, situated well behind level of posterior orbital margin and slightly below level of antennal spine. Antero-lateral angle of carapace (Figs. 3, 4A, C-K) blunt, not produced.

Abdominal segments (Fig. 3) smooth. Third segment slightly produced posterodorsally. Pleura all broadly rounded. Sixth abdominal segment 1.6 times as long as fifth (relatively longer in smaller specimens), posteroventral angle feebly produced, rounded, posterolateral angle acute.
Telson (Fig. 5A) 1.2 times as long as sixth abdominal segment and 3.1 times longer than anterior width; lateral margins converge posteriorly; two pairs of small sized submarginal dorsal spines present at 0.80 and 0.85 of telson length; posterior margin rounded, 0.43 of anterior width, with three pairs of spines. Lateral spines short, slightly longer than dorsal spines. Intermediate spines well developed, about 0.17 of telson length, 1.8 times length of submedian spines.

Eyes (Fig. 4A, B) well developed. Cornea globular, with distinct accessory pigment spot dorsally. Eyestalks slightly more than twice as long as proximal width, slightly swollen proximally. 


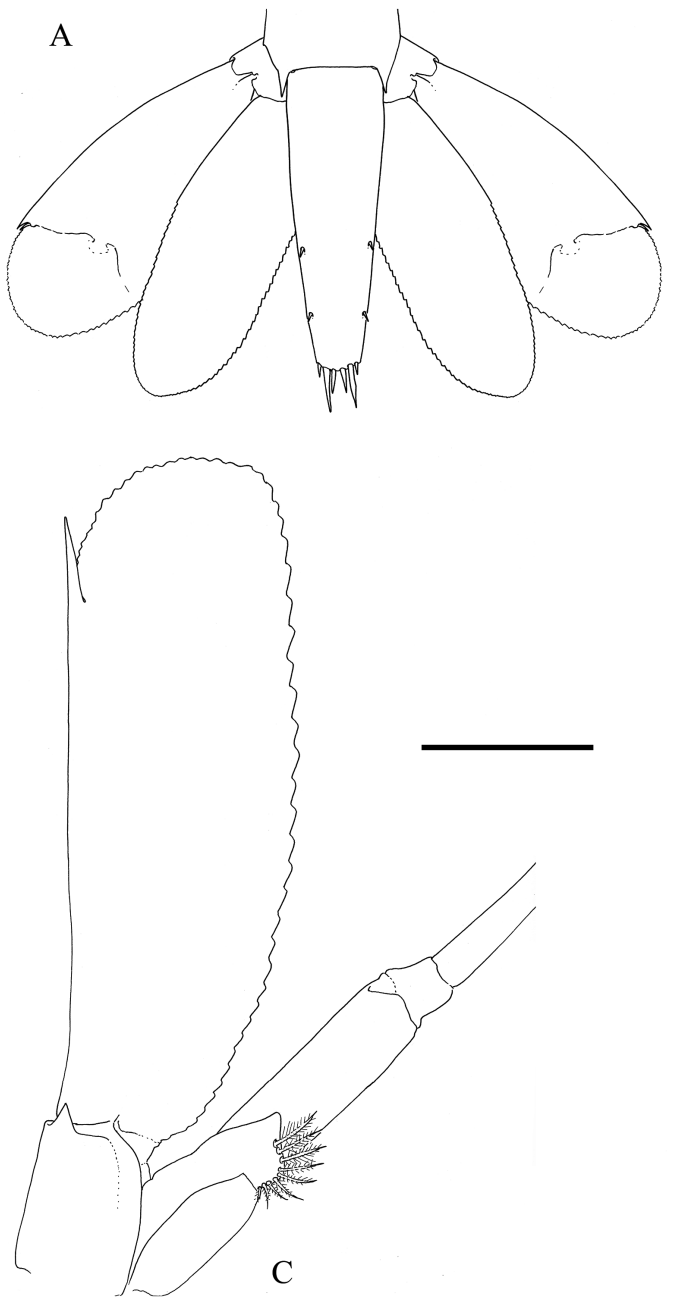

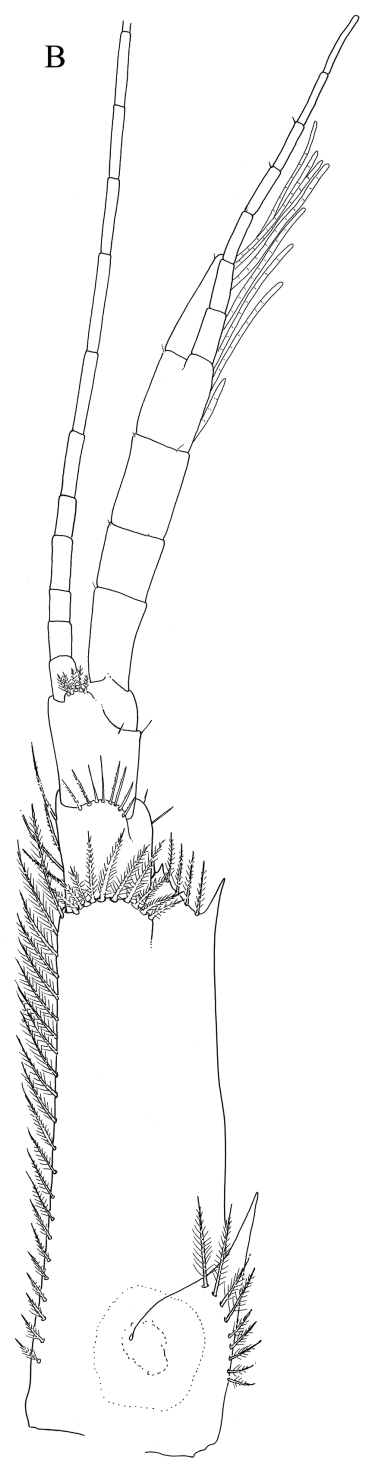

Fig. 5. Periclimenes rathbunae $\mathrm{Schmitt,}$ 1924. Ovigerous female, pocl. $2.18 \mathrm{~mm}$, RMNH.CRUS.D.57031: A, tailfan, dorsal view. Ovigerous female, pocl. $1.88 \mathrm{~mm}$, OUMNH.ZC.2015-02-008; B, antennula, dorsal view; $\mathrm{C}$, antenna, ventral view. Scale bar: $\mathrm{A}=1 \mathrm{~mm} ; \mathrm{B}, \mathrm{C}=0.8 \mathrm{~mm}$.
Antennular peduncle (Fig. 5B) exceeding tip of rostrum by distal one or two segments. Proximal segment long, slender, 3.0 times longer than wide; stylocerite slender, acute, reaching almost to middle of segment; lateral margin straight, anterolateral margin produced, angular, with distolateral tooth and row of setae; medial ventral margin without tooth. Statocyst containing granular statolith. Intermediate and distal segments short, together equal to 0.38 of proximal segment length. Upper outer flagellum biramous, with first 4-5 segments fused. Aesthetascs present on distal 4 segments of fused part and short free ramus. Shorter free ramus uni-segmented, longer rami with 6-7 segments.
Lower inner flagellum slender, slightly longer than upper flagellum.

Antennal basicerite (Fig. 5C) with lateral tooth. Ischiocerite and merocerite normal. Carpocerite slender, reaching 0.4 of length of scaphocerite. Scaphocerite long, rather slender, with lamella slightly overreaching distal margin of antennular peduncle. Lateral border straight, ending in acute large distolateral tooth. Lamella extending beyond distolateral tooth, feebly angulated distomedially, about 2.9 times longer than broad, with greatest width at about half of its length.

Epistome and labrum normal.

Second and third thoracic sternites unarmed. 


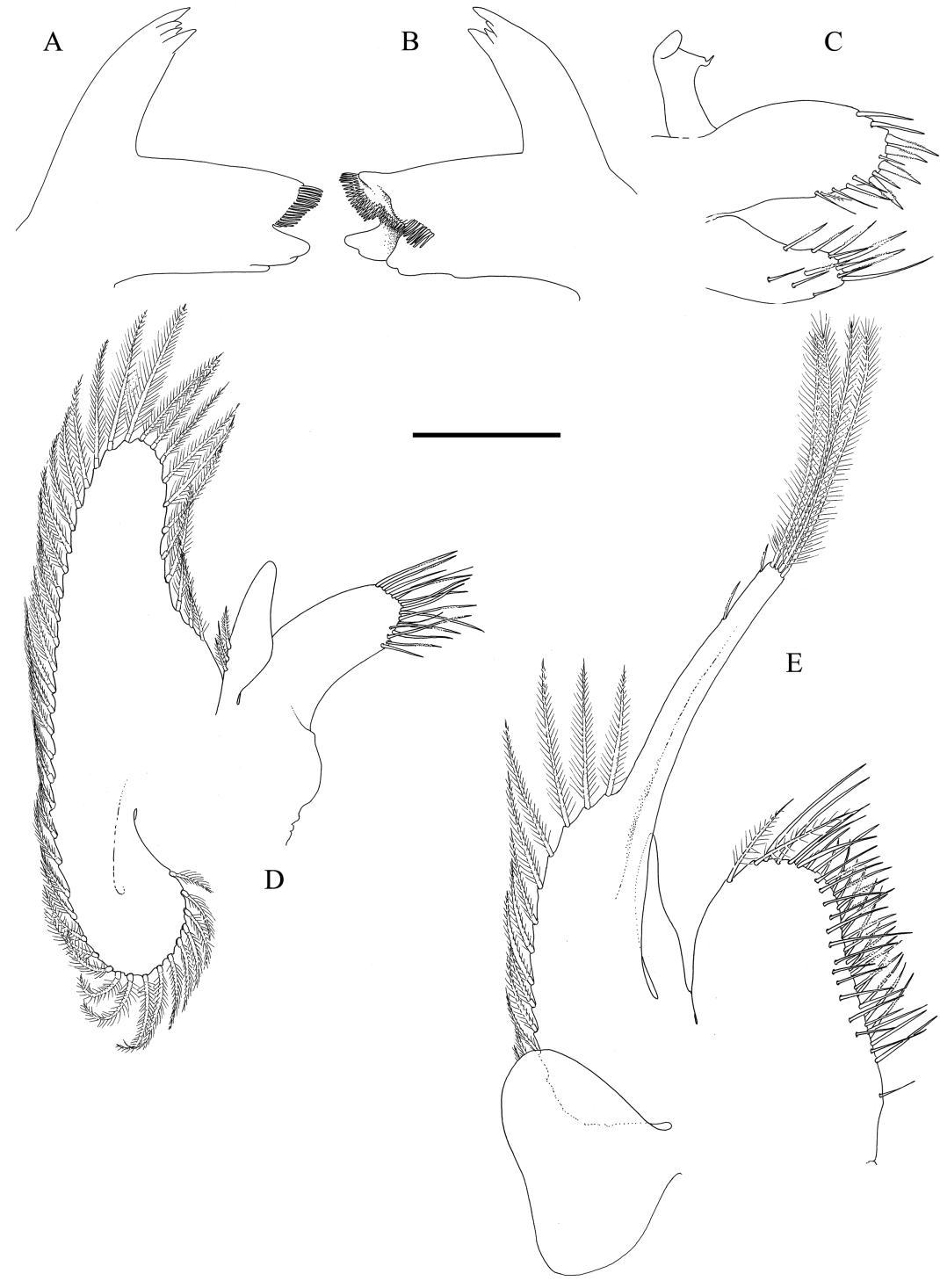

Fig. 6. Periclimenes rathbunae Schmitt, 1924, ovigerous female, pocl. $1.88 \mathrm{~mm}$, OUMNH.ZC.2015-02-008: A, right mandible, dorsal view; B, right mandible, ventral view; $C$, right maxillula, dorsal view; D, right maxilla, dorsal view; E, right first maxilliped, dorsal view. Scale bar: $\mathrm{A}-\mathrm{E}=0.4 \mathrm{~mm}$.
Fourth thoracic sternite with short medial process and shallow lateral carinae posteromedial of first pereiopods.

Fifth thoracic sternite with distinct lateral plates posteromedial of second pereiopods.

Sixth to eighth thoracic sternites unarmed.

Mandible (Fig. 6A, B) with cylindrical molar process bearing a few brushes of setae distally. Incisor process slender, with four well developed teeth distally, of which lateralmost slightly enlarged. Mandible without palp.

Maxillula (Fig. 6C) with upper lacinia rectangular with row of few serrulate spines and slender setae me- dially; lower lacinia more slender, with few serrulate setae distally; palp bilobed, medial lobe with single short recurved simple seta.

Maxilla (Fig. 6D) with short tapering non-setose palp with few plumose setae laterally. Basal endite well developed, not bilobed, with row of about 15 also short, stout and blunt, with about six simple setae distally. Coxal endite obsolete, median margin convex, without setae, medial region slightly convex. Scaphognathite normal, widest centrally, about 23.82 times longer than broad, with marginal plumose setae.

First maxilliped (Fig. 6E) with short, slender, tapering palp without setae. Basal region broad, not dis- 


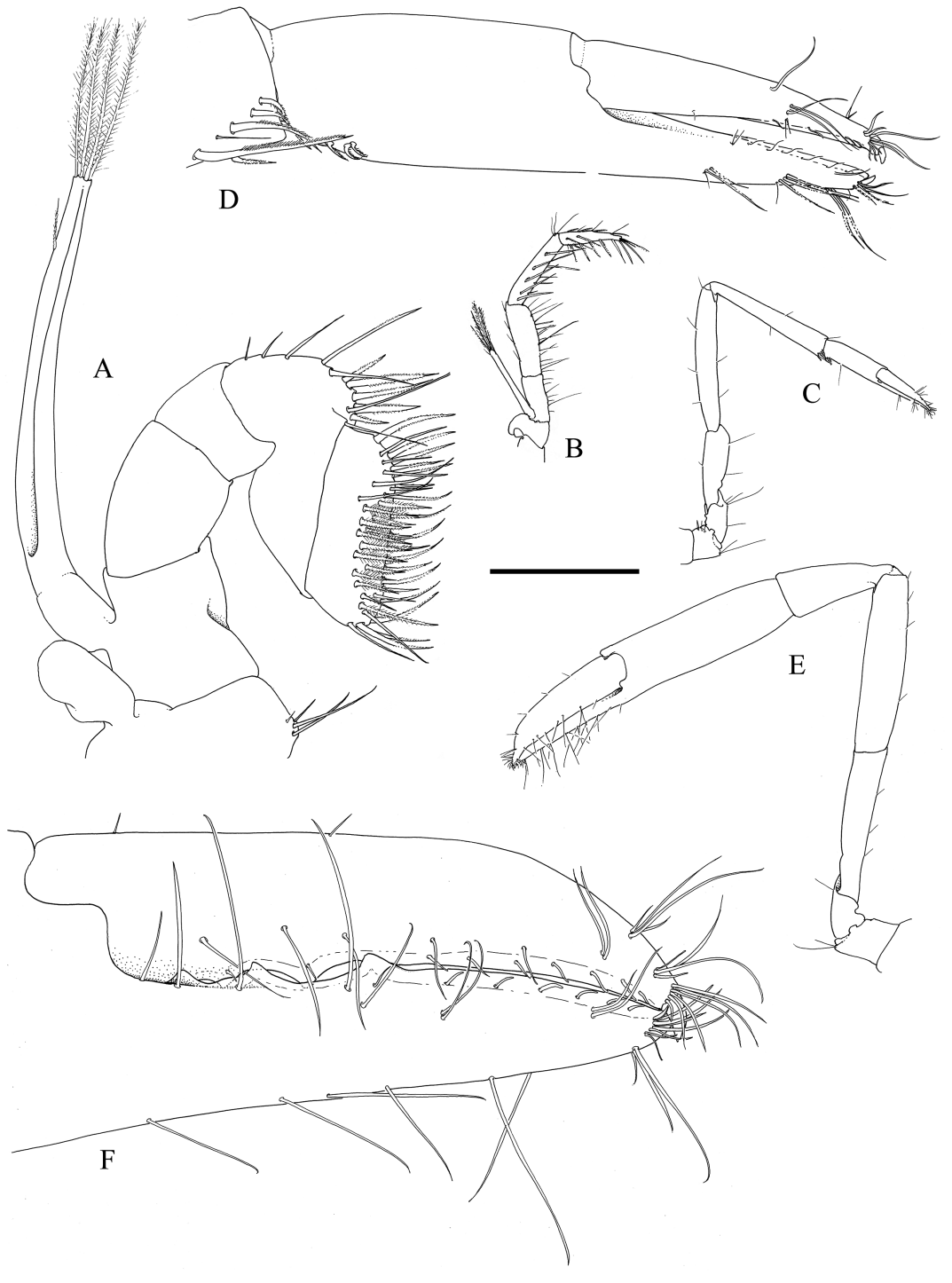

Fig. 7. Periclimenes rathbunae Schmitt, 1924, ovigerous female, pocl. $1.88 \mathrm{~mm}$, OUMNH.ZC.2015-02-008: A, right second maxilliped, dorsal view; B, right third maxilliped, dorsal view; C, right first pereiopod; D, idem, chela; E, left major second pereiopod; F, idem, chela. Scale bar: A, D, F = $0.4 \mathrm{~mm}$; B, C, E = $1 \mathrm{~mm}$. tinctly separated from the coxal region. Median margin sparsely provided with setulose and slender simple setae. Caridean lobe distinct, with coarsely setulose plumose marginal setae. Flagellum of exopod well developed with 4 long plumose distal setae and few short subdistal setae. Epipod indistinctly bilobed.

Second maxilliped (Fig. 7A) with dactylar segment narrow, 2.4 times longer than wide, straight medially, densely fringed with with numerous coarsely serrulate, spiniform, and long curled finely serrulate setae medially. Propodal segment longer than dactylar segment, almost twice as long as wide, with a subrectangular distomedial angle not produced, with few long serrulate setae. Carpus short, unarmed. Meral segment short, not excavate, without setae. Ischium fused to basis. Basis with long slender exopod exceeding length of endopod, with 4 long plumose setae distally and one short plumose seta subdistally. Coxa slightly produced medially, with few small simple setae medially, rounded small oblong epipod laterally.

Third maxilliped (Fig. 7B) slender. Terminal segment 3.4 times longer than proximal width, slightly shorter than length of penultimate segment, with few serrulate and simple setae medially. Penultimate segment slender, 4.4 times longer than wide. Meral segment short, 0.57 of length of penultimate segment, 


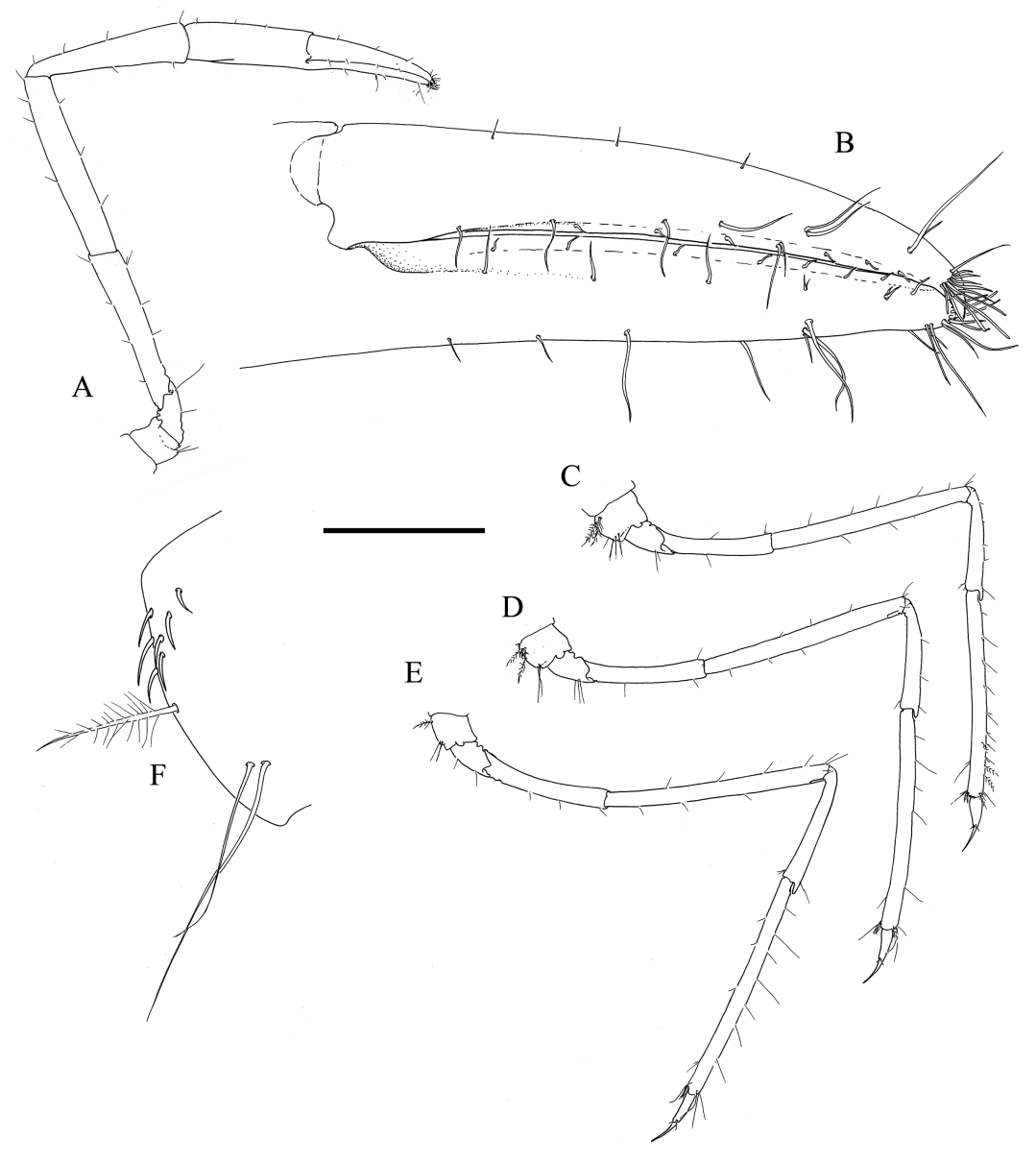

Fig. 8. Periclimenes rathbunae Schmitt, 1924, ovigerous female, pocl. $1.88 \mathrm{~mm}$, OUMNH.ZC.2015-02-008: A, right minor second pereiopod; $\mathrm{B}$, idem, chela; $\mathrm{C}$, right third pereiopod; $\mathrm{D}$, right fourth pereiopod; E, right fifth pereiopod; F, coxa right fourth pereiopod. Scale bar: A, $\mathrm{C}-\mathrm{E}=1 \mathrm{~mm} ; \mathrm{B}=0.4 \mathrm{~mm} ; \mathrm{F}=0.2 \mathrm{~mm}$.

twice as long as wide, clearly separated from short ischial segment. Ischial segment half length of meral segment, as long as wide, distinctly separated from basal segment. Basal segment oblong, as long as meral segment. Exopod reaching mid length of meral segment, with 4 distal and 2 subdistal plumose setae. Coxa not produced medially, with rounded lateral plate and small rudimentary arthrobranch.

First pereiopod (Fig. 7C) slender, reaching distal margin of scaphocerite. Chela with palm subcylindrical, straight, 2.0 times longer than wide. Fingers (Fig. 7D) as long as palm, straight not subspatulate, with brushes of few setae in distal part, cutting edges entire, tips of fingers hooked. Cleaning setae present proximally on palm and distoventral part of carpus. Carpus 1.0 times length of chela, 5.5 times longer than wide. Merus about as long as carpus, twice length of ischium. Basis and coxa without special features.

Second pereiopods, subequal in length, usually dissimilar. Major second pereiopod (Fig. 7E) extending beyond antennular peduncle with chela. Chela with palm subcylindrical, straight, about three times as long as wide. Fingers (Fig. 7F) 0.75 of palm length. Dactylus wider than fixed finger, with dorsolateral longitudinal carina in larger specimens, with brushes of setae in distal part, unguis strongly hooked, cutting edge with 0-3 slightly recurved teeth proximally, decreasing in size proximally. Fixed finger with tip strongly hooked, with 0-4 slightly recurved teeth in proximal half, decreasing in size proximally. Carpus, merus and ischium unarmed, their length ratios of $0.5,1.0$ and 0.8 times length of palm. Basis and coxa without special features. Minor second pereiopod (Fig. 8A). Chela with fingers (Fig. 8B) as long as subcylindrical palm, 


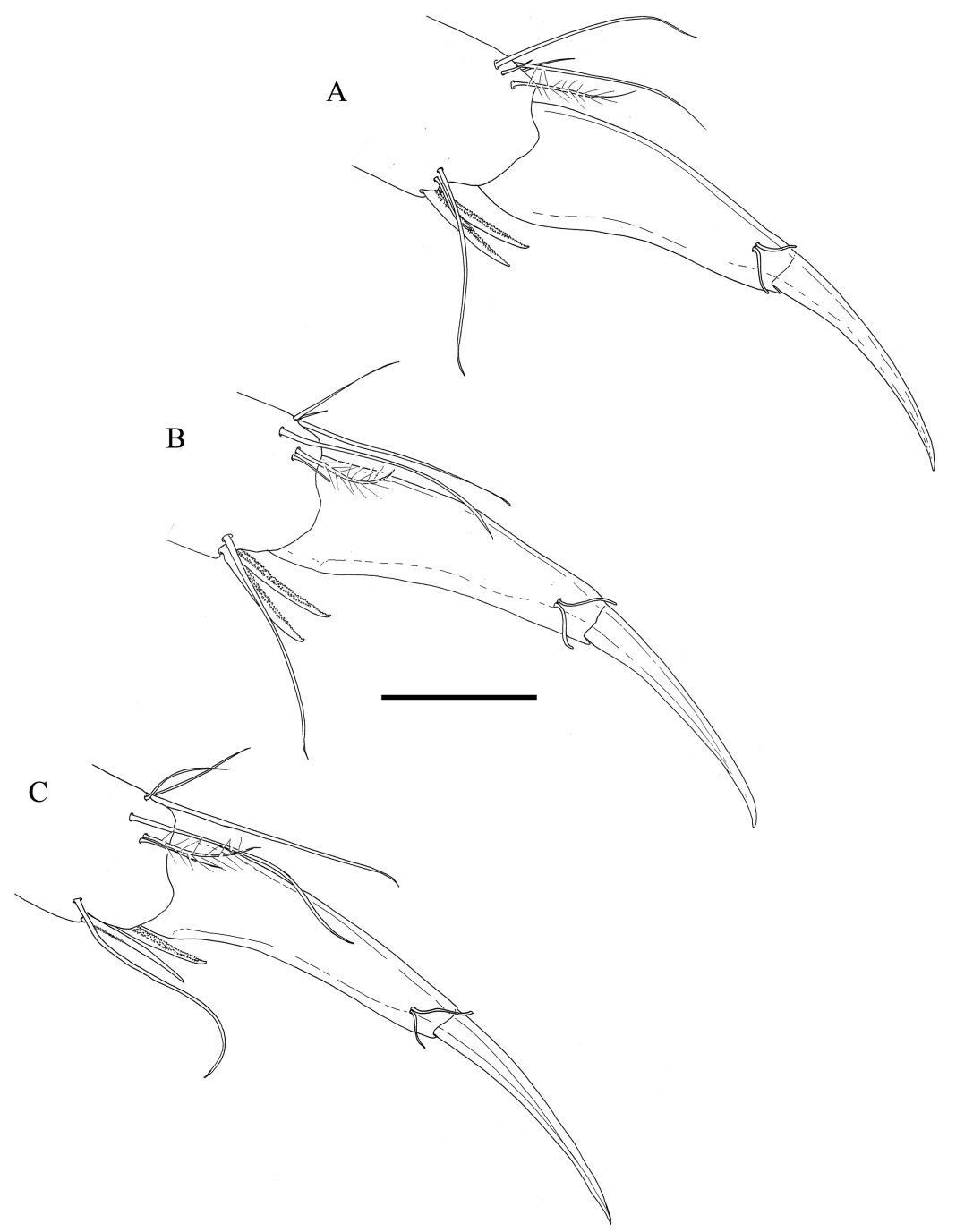

Fig. 9. Periclimenes rathbunae Schmitt, 1924, ovigerous female, pocl. $1.88 \mathrm{~mm}$, OUMNH.ZC.2015-02-008: associated with Dendrogyra cylindrus Ehrenberg, 1834: A, dactylus right third pereiopod; $\mathrm{B}$, idem, fourth right pereiopod; $\mathrm{C}$, idem, fifth right pereiopod. Scale bar $=0.2 \mathrm{~mm}$.

fingers distally hooked, cutting edges entire; carpus slightly longer than palm, gradually increasing in distally; merus slightly longer than carpus; ischium as long as carpus.

Ambulatory pereiopods (Fig. 8C-E) slender, similar in form, slightly increasing in in length from third to fifth. Dactylus (Figs. 9, 10) slender, uniformly tapering, unarmed, about 0.25 of propodus length, 5.5 times as long as proximal width, with slender unguis almost as long as corpus. Propodus about 12-15 times longer than wide, with two distoventral spines in third and fourth and one in fifth pereiopod; distoventral spines with fine denticulation on flexor margin. Carpus, merus and ischium $0.47,1.0$ and 0.53 of propodus length, unarmed (Fig. 4C, D). Coxa of fourth pereiopod in female with patch of short curved spines proximoventrally (Fig. 8F).
Endopod of first pleopod in ovigerous female (Fig. 11A) short, 0.25 of length of exopod, with long plumose setae along its entire margin. Endopod of first pleopod in male (Fig. 11B) short, 0.41 times length of exopod, distally rounded, with 3 long plumose setae along lateral margin and one long plumose seta in proximal part of medial margin with one small short seta somewhat more anteriorly. Endopod of second pleopod in male (Fig. 11C), 0.77 times length of exopod. Appendix masculina long and slender, almost twice as long as appendix interna, with five serrate long setae distally.

Uropods (Fig. 5A) extending beyond tip of telson. Protopodite unarmed laterally. Exopod with lateral border almost straight, entire, terminating in a small tooth with small mobile spine medially, about 2.3 times longer than wide, about as long as endopod. 


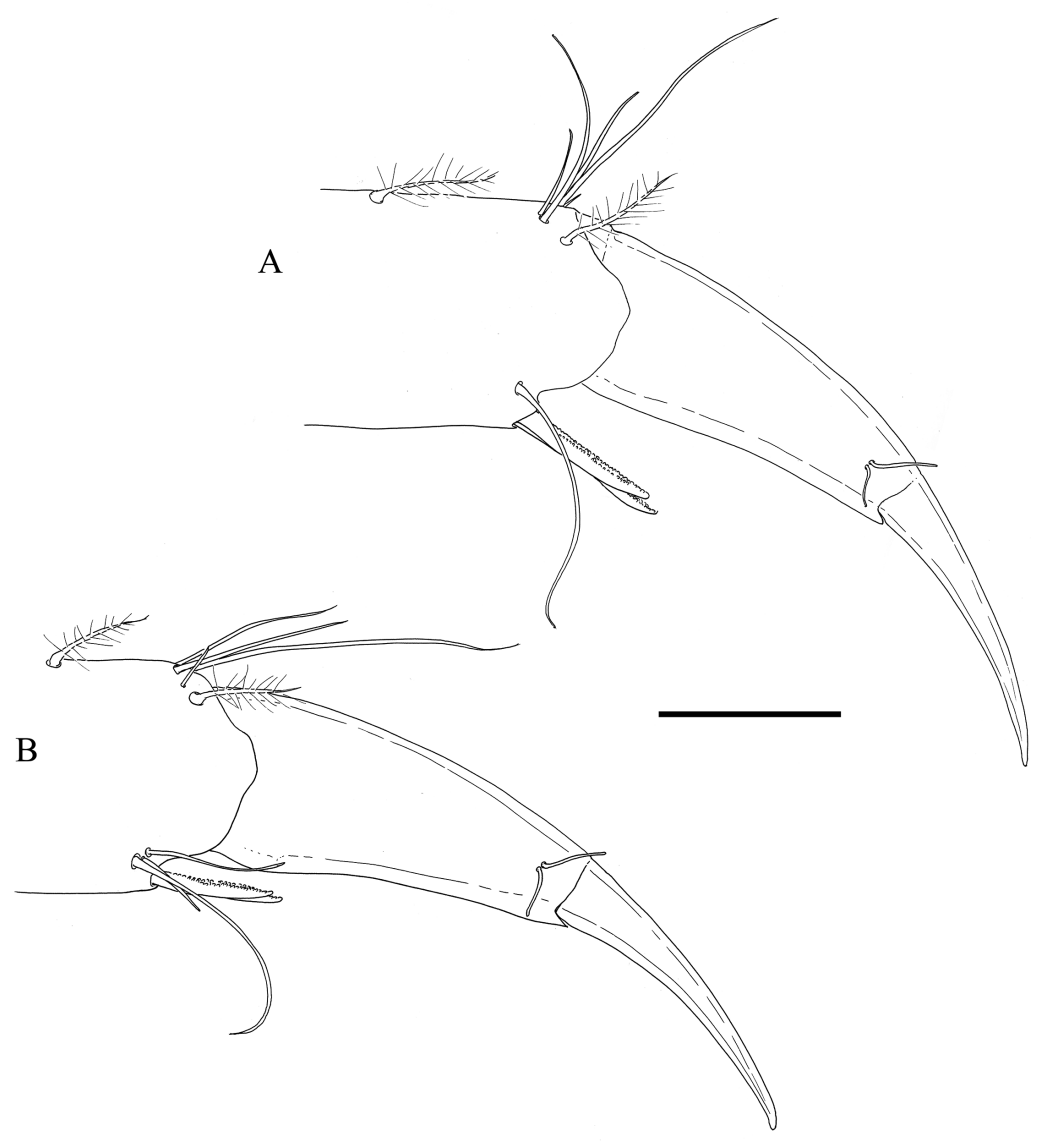

Fig. 10. Periclimenes rathbunae Schmitt, 1924, associated with Stichodactyla helianthus (Ellis, 1768): A, dactylus right third pereiopod, male, pocl. $2.20 \mathrm{~mm}$, RMNH.CRUS.D.57049; B, idem, male, pocl. $1.75 \mathrm{~mm}$, RMNH.CRUS.D.57045. Scale bar $=0.2 \mathrm{~mm}$.

Table 3. Additional sequences obtained from Naturalis Biodiversity Center with species name, sample number, voucher registration number,

Species

Locality

\begin{tabular}{lllll}
\hline & Sample nr & Voucher reg. nr & Country & Coordinates \\
\hline Periclimenes rathbunae Schmitt, 1924 & G014 & RMNH.CRUS.D.53148 & Carmabi Reef & $12.272000 \mathrm{~N}, 68.969167 \mathrm{~W}$ \\
Periclimenes rathbunae Schmitt, 1924 & G019 & RMNH.CRUS.D.53150 & Hilton Reef & $12.122083 \mathrm{~N}, 68.968833 \mathrm{~W}$ \\
Periclimenes rathbunae Schmitt, 1924 & JE-009 & RMNH.CRUS.D.57044 & Marie Pampoen/ Carpile & $12.095028 \mathrm{~N}, 68.911944 \mathrm{~W}$ \\
Periclimenes rathbunae Schmitt, 1924 & JE-013 & RMNH.CRUS.D.57048 & Superior Producer & $12.089306 \mathrm{~N}, 68.943194 \mathrm{~W}$ \\
Periclimenes rathbunae Schmitt, 1924 & JE-014 & RMNH.CRUS.D.57044 & Marie Pampoen/ Carpile & $12.095028 \mathrm{~N}, 68.911944 \mathrm{~W}$ \\
Periclimenes rathbunae Schmitt, 1924 & JE-015 & RMNH.CRUS.D.57047 & Hilton Reef & $12.122083 \mathrm{~N}, 68.968833 \mathrm{~W}$ \\
Periclimenes rathbunae Schmitt, 1924 & JE-016 & RMNH.CRUS.D.57037 & Carmabi Reef & $12.272000 \mathrm{~N}, 68.969167 \mathrm{~W}$ \\
Periclimenes yucatanicus (Ives, 1890) & G015 & RMNH.CRUS.D.53149 & Carmabi Reef & $12.272000 \mathrm{~N}, 68.969167 \mathrm{~W}$ \\
Periclimenes yucatanicus (Ives, 1890) & G017 & RMNH.CRUS.D.53151 & Drielstraat & $12.095028 \mathrm{~N}, 68.911944 \mathrm{~W}$ \\
Ancylomenes pedersoni (Chace, 1958) & G004 & RMNH.CRUS.D.53153 & Carmabi Reef & $12.272000 \mathrm{~N}, 68.969167 \mathrm{~W}$ \\
Ancylomenes pedersoni (Chace, 1958) & G012 & RMNH.CRUS.D.53154 & Carmabi Reef & $12.272000 \mathrm{~N}, 68.969167 \mathrm{~W}$ \\
Ancylomenes pedersoni (Chace, 1958) & G010 & RMNH.CRUS.D.53147 & Carmabi Reef & $12.272000 \mathrm{~N}, 68.969167 \mathrm{~W}$
\end{tabular}




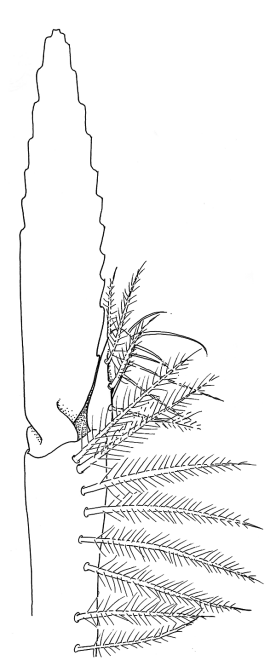

A

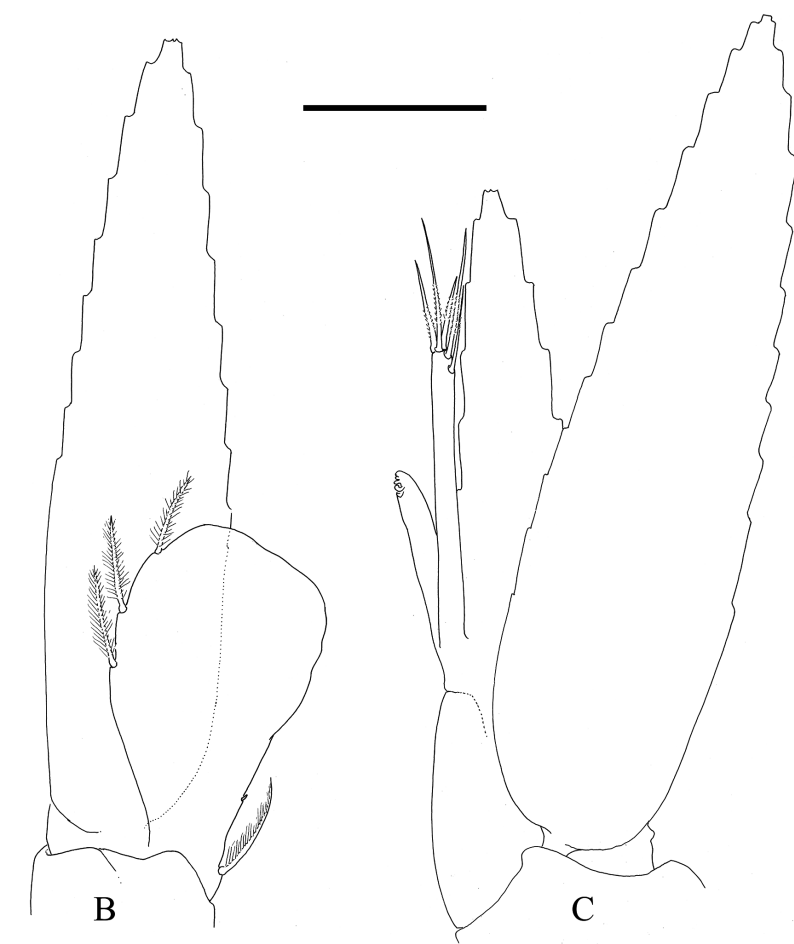

Fig. 11. Periclimenes rathbunae Schmitt, 1924, RMNH.CRUS.D.57032. A, first right pleopod, ovigerous female, pocl. $2.18 \mathrm{~mm}$; B, first right pleopod, male, pocl. $1.63 \mathrm{~mm}$; right second pleopod, male, pocl. $1.63 \mathrm{~mm}$. Scale bar: A = 0,8 $\mathrm{mm} ; \mathrm{B}, \mathrm{C}=0.4 \mathrm{~mm}$.

sampling locality, host, and GenBank accession numbers.

GenBank accession \#

\section{Host class: subclass: order: species}

Anthozoa: Hexacorallia: Actiniaria: Stichodactyla helianthus Anthozoa: Hexacorallia: Actiniaria: Stichodactyla helianthus Anthozoa: Hexacorallia: - : -

Anthozoa: Hexacorallia: Actiniaria: Stichodactyla helianthus Anthozoa: Hexacorallia: - : -

Anthozoa: Hexacorallia: Actiniaria: Stichodactyla helianthus Anthozoa: Hexacorallia: Actiniaria: Stichodactyla helianthus Anthozoa: Hexacorallia: Actiniaria: Condylactis gigantea Anthozoa: Hexacorallia: Actiniaria: Condylactis gigantea Anthozoa: Hexacorallia: Actiniaria: Bartholomea annulata Anthozoa: Hexacorallia: Actiniaria: Bartholomea annulata Anthozoa: Hexacorallia: Actiniaria: Condylactis gigantea

\section{COI}

KX090120

KX090121

KX090122

$-$

KX090123

KX090124

KX090125

KX090126

KX090127

KX090128

$-$
$16 S$

H3

$\begin{array}{ll}- & - \\ \text { KX090097 } & \text { KX090141 } \\ \text { KX090098 } & \text { KX090142 } \\ \text { KX090099 } & - \\ \text { KX090100 } & \text { KX090143 } \\ - & \text { KX090144 } \\ \text { KX090101 } & - \\ \text { KX090102 } & - \\ \text { KX090103 } & - \\ \text { KX090104 } & - \\ \text { KX090105 } & -\end{array}$


From ca. 30-80 eggs of ca. $0.5 \mathrm{~mm}$ in diameter present under abdomen depending on size of female.

Size. Ovigerous females ranging from pocl. 1.75$5.25 \mathrm{~mm}$, maximum size of males $2.60 \mathrm{~mm}$.

Colour. Juveniles are largely transparent. Adult specimens with distinct pattern of red and white dots and lines. For detailed descriptions of juvenile and adult colour patterns see Spotte et al. (1991).

Remarks on variation. In the type description no mention is made of teeth on the cutting edges of the dactylus and fixed finger of the major chela of the second pereiopods. When checking the holotype (ZMA DE240829) three recurved teeth were observed in the proximal part of both dactylus and fixed finger. Also Holthuis (1951) did not note these teeth as the specimen he described from the Tortugas is lacking the major second pereiopod. The armature of the major second chela is rather variable ranging from entire cutting edges to three on the dactylus and four on the fixed finger. If teeth are present, usually the fixed finger has one more than the dactylus. There is no clear relation of the armature with size. However, in the smallest specimens the number of teeth is usually lower than in adult specimens. In adult specimens though, major second chelae with entire cutting edges are not uncommon. No relation between armature and gender of the specimens was observed.

The dorsolateral flange on the dactylus of the major second pereiopod is usually more developed in larger specimens. In those specimens with a very well developed dorsolateral flange, the dactylus is distinctly longer than the fixed finger. However, several of the larger specimens have been observed without a dorsolateral flange. In few specimens with a dorsolateral flange on the major second chela such a flange is also present on the minor second chela.

The major second pereiopod is occurring on the right or left side in equal numbers (antisymmetric). 